Article

\title{
Analysis of Glucosinolate Content, Composition and Expression Level of Biosynthesis Pathway Genes in Different Chinese Kale Varieties
}

\author{
Lu Tong ${ }^{1,2}$, Shanhan Cheng 1,2,*, Honghao Lv ${ }^{2,3} \mathbb{D}$, Chengzhi Zhao ${ }^{1,2}$, Jie Zhu ${ }^{1,2}$, Pingwu Liu ${ }^{1,2}$, \\ Zhiwei Wang ${ }^{1,2} \mathbb{D}$, Limei Yang ${ }^{2,3}$ and Yangyong Zhang ${ }^{2,3}$
}

1 Key Laboratory for Quality Regulation of Tropical Horticultural Crops of Hainan Province, College of Horticulture, Hainan University, Haikou 570228, China; LuTong123452@outlook.com (L.T.); Zcz1904726466@163.com (C.Z.); jasperjie@aliyun.com (J.Z.); gxulpw@gxu.edu.cn (P.L.); zwwang22@163.com (Z.W.)

2 Fang Zhiyuan Academician Team Innovation Center of Hainan Province, Haikou 570228, China; lvhonghao@caas.cn (H.L.); yanglm@mail.caas.net.cn (L.Y.); zhyy888@hotmail.com (Y.Z.)

3 Institute of Vegetables and Flowers, Chinese Academy of Agricultural Sciences, Beijing 100081, China

* Correspondence: 990865@hainanu.edu.cn

check for updates

Citation: Tong, L.; Cheng, S.; Lv, H.; Zhao, C.; Zhu, J.; Liu, P.; Wang, Z.; Yang, L.; Zhang, Y. Analysis of Glucosinolate Content, Composition and Expression Level of Biosynthesis Pathway Genes in Different Chinese Kale Varieties. Horticulturae 2021, 7, 398. https://doi.org/10.3390/ horticulturae7100398

Academic Editor: Luigi De Bellis

Received: 25 August 2021

Accepted: 8 October 2021

Published: 14 October 2021

Publisher's Note: MDPI stays neutral with regard to jurisdictional claims in published maps and institutional affiliations.

Copyright: (c) 2021 by the authors. Licensee MDPI, Basel, Switzerland. This article is an open access article distributed under the terms and conditions of the Creative Commons Attribution (CC BY) license (https:/ / creativecommons.org/licenses/by/ $4.0 /)$.

\begin{abstract}
The content and component of glucosinolates in edible stems and leaves of eight Chinese kale varieties from Japan and eight varieties from China were determined by HPLC-MS. Simultaneously, the expression levels of glucosinolate biosynthesis pathway genes from four varieties with high and low total glucosinolate contents were analyzed by the qRT-PCR method. Four types of aliphatic glucosinolates (A-GLSs: GRA, SIN, GNA and GER) and indole glucosinolates (I-GLSs: 4-HGBS, GBS, 4-MGBS and NGBS) were detected in the stems and leaves of 16 varieties, and no aromatic glucosinolates (R-GLSs) were detected. A-GLSs account for more than $80.69 \%$ of the total content of total glucosinolates (T-GLSs), in which GNA and GRA are the main components of stems and leaves. Among Japanese varieties, QB1 has higher content of A- and T-GLSs, while that of XLB was lower; however, the corresponding varieties were $\mathrm{ZH}$ and $\mathrm{DSHH}$ in Chinese varieties. Among the above four varieties, the expression levels of SOT16, CYP83B1, SOT17, CYP83A1 and MAM1 genes were significantly higher in the varieties with higher GLSs; the expression levels of SOT16 and CYP83B1 were consistent with the content of I-GLSs; and SOT17, CYP83A1 and MAM1 expression levels were consistent with A-GLSs content. At the same time, the expression levels of SOT16 and CYP83B1 in the leaves were higher than those in the stems. CYP83A1 and MAM1 genes were less expressed in the leaves than in the stems of lower content varieties. It is speculated that these genes may be the key genes regulating GLS biosynthesis in Chinese kale.
\end{abstract}

Keywords: Chinese kale; glucosinolate content and component; HPLC-MS; gene expression

\section{Introduction}

Chinese kale (Brassica oleracea var. alboglabra) is a native Chinese vegetable belonging to the family of Brassicaceae and its edible organ includes tender stems, young leaves and bolting stems which are rich in vitamin C, carotene, calcium, magnesium, potassium, dietary fiber and glucosinolates [1]. Numerous epidemiological studies have demonstrated that the breakdown products of glucosinolates, such as isothiocyanate (ITCs), sulforaphane (SF) and indole-3-carbinol (I3C), are not only helpful to reduce the risk of cardiovascular disease, but also contribute to decreasing the incidence rate of carcinogenesis including breast, prostate, lung and pancreatic cancer [2-4]. Furthermore, GLSs and its derivatives have an important role against the invasion of pathogens and herbivores $[5,6]$, and are also responsible for the specific flavor of Brassica plants [7].

So far, more than 200 kinds of natural glucosinolates have been found in 16 families of dicotyledons, and more than 120 different glucosinolates have been confirmed in 
cruciferous vegetables [8,9]. However, only a few kinds of glucosinolates are abundant in cruciferous vegetables, such as gluconapin (GNA) and glucobrassicanapin (GBN) in Pak choi (B. rapa L.) [10,11]; GBN, glucobrassicin (GBS) and progoitrin (PRO) in Chinese cabbage (B. rapa ssp. pekinensis) [10-12]; sinigrin (SIN) in Ethiopian mustard (B. carinata A. braun) [13]; glucoiberin (GIB) in Mediterranean cabbage (B. fruticulosa Cirillo) [14]; and sinigrin (SIN) in Indian mustard (B. juncea Czem.) [15]. Even in Brassica oleracea, the most abundant component and content of glucosinolates are also affected by species, varieties, cultivation conditions and environmental factors [16,17]. In red cabbage (B. oleracea L. var. Capitata f. rubra DC.), the content of GRA is as high as $48.2 \mu \mathrm{mol} / 100 \mathrm{~g} \mathrm{FW}$, accounting for $32.0 \%$ of the total glucosinolate content of $150.8 \mu \mathrm{mol} / 100 \mathrm{~g} \mathrm{FW}$, which is the most abundant component, but GBS is the most abundant component in Brussels sprout ( $B$. oleracea L. var. gemmifera DC.), with a content range of 327.8-469.4 $\mu \mathrm{mol} / 100 \mathrm{~g}$ FW $[18,19]$. The content and composition of glucosinolates in different varieties of Chinese kale are also different and A- and I-GLSs are mainly composed of bolting stems and young leaves, among which GNA and GER are the main glucosinolates [20,21]. However, the content and composition of glucosinolate in Xianggu Chinese kale with tender stems as the main edible organ are rarely reported, and are also not clear for Chinese kale varieties introduced in China from Japan.

GLSs can be classified into A-GLSs, I-GLSs and R-GLSs according to different sources of side chain amino acid precursors [22]. The glucosinolate biosynthesis pathway of plants, especially cruciferous plants, has been basically established in Arabidopsis thaliana, a model plant (Figure 1), which consists of three steps: extension of amino acid side chain, synthesis of core structure and secondary modification of side chain [23]. Firstly, the aliphatic precursor methionine is successively catalyzed by branched-chain amino acid transaminase (BCAT), methylthioalkylmalate synthase (MAMs), isopropyl malate isomerase (IPMI) and isopropyl malate dehydrogenase (IPM-DH) to form elongated amino acids with side chains extending a carbon atom group (-CH2-) [24,25]. Secondly, amino acids or amino acids via side chain extension are successively catalyzed by CYP79 enzymes of the cytochrome P450 family (CYP79F1 and CYP79F2 for the aliphatic group, CYP79B2 and CYP79B3 for the indole group, $C Y P 79 A 2$ for aromatic glucosinolate) [26,27], the CYP83 enzyme family (CYP83A1 for aliphatic and CYP83B1 for indole) [28], C-S lyase (SUR1) [29], glucosyltransferase (UGT74) (UGT74B1 and UGT74C1 for aliphatic and UGT74B1 for indole) [30,31] and sulfonyltransferases (SOTs) (SOT17 and SOT18 for aliphatic, SOT16 for indole) [32], and finally converted into basic glucosinolate core structure. Third, the amino acid side chains of the core structure of glucosinolates undergo different secondary modifications to form different glucosinolates, among which aliphatic glucosinolates are formed by sulfur oxidation, hydroxylation, benzoylation and mustardylation, and indole glucosinolates are formed by hydroxylation and methoxylation [33,34]. Many key genes involved in the glucosinolate biosynthesis pathway, such as BACT, MAM, CYP79F, CYP83, UTG74B and $S O T$, have been cloned and their functions have been confirmed in Arabidopsis, cabbage or broccoli $[32,35]$. Although the glucosinolate transport protein gene GTR from Chinese kale is cloned and functionally identified [36], and the expression patterns of BCAT4, MAM1 and CYP94F1 involved in glucosinolate biosynthesis are studied [37]; additional related genes still need to be confirmed in regulating the biosynthesis and composition of glucosinolates in Chinese kale.

In this study, eight Chinese kale varieties introduced from Japan and eight Chinese kale varieties produced in China were used to analyze the glucosinolate component and content of the edible parts of the stems and leaves of the varieties by the HPLC-MS method. Then, the varieties with high glucosinolate content were screened for further promotion and application. At the same time, the difference expressions of key genes of the glucosinolate biosynthesis pathway in Chinese kale varieties with higher or lower glucosinolate content are helpful to find more genes related to the content or component of glucosinolate, and lay the foundation for further improvements in beneficial glucosinolate components in Chinese kale by genetic engineering methods. 


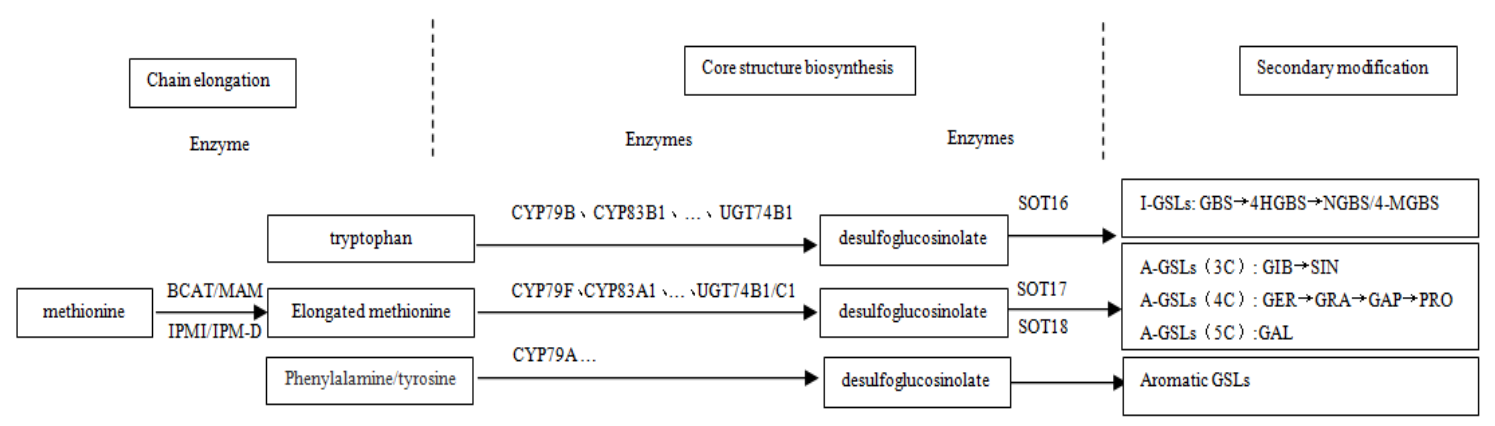

Figure 1. Schematic diagram of the glucosinolate biosynthesis pathway of Cruciferae plants $[23,38]$.

\section{Materials and Methods}

\subsection{Plant Materials}

The sixteen cultivated Chinese kale varieties used in this study are shown in Table 1. The seeds of each variety were sterilized for $10 \mathrm{~min}$ in $20 \%$ bleach (KAO, Japan), and washed with distilled water 5-6 times. Then, seeds were sown in a pot on 23 October 2019 and transplanted to the experimental base of the College of Horticulture in Hainan University on 20 November 2019. The experiment was arranged in random blocks and repeated 3 times. The area of each plot was 6 square meters and the row spacing was $15 \times 25 \mathrm{~cm}$. The cultivation and management methods are the same for all varieties.

Table 1. Name and source of experimental Chinese kale varieties.

\begin{tabular}{cccccc}
\hline Name & Abbreviation & Source & Name & Abbreviation & Source \\
\hline Shun bao & SB & Japan & Tai wan di xian & TWDX & China \\
Lv bao & LB & Japan & Kuai da si ji & KDSJ & China \\
Qi bao & QB1 & Japan & Yicai & YC & China \\
Cui bao & CB & Japan & Da sun huang hua & DSHH & China \\
Xiang bao & XB & Japan & Te zao si ji da sun & TZSJDS & China \\
Qi bao & QB2 & Japan & Da sun chi hua & DSCH & China \\
De ba & DB & Japan & Zhong hua & ZH & China \\
Xi lai bao & XLB & Japan & Si ji tian & SJT & China \\
\hline
\end{tabular}

\subsection{GLSs Extraction and Purification}

When the flower stalks and basal leaves of kale were roughly at the same height, and the flower balls were harvested but did not open, the edible stem and leaf parts of Chinese kale were separated quickly and cut into $1 \mathrm{~cm}$ sections, quickly mixed and stored in $-80^{\circ} \mathrm{C}$. After that, the samples were placed in a freeze dryer for $24 \mathrm{~h}$ to remove moisture from the tissue. The freeze-dried samples were ground into powder by a powder grinder and put into a plastic sealing bag and blue desiccant bag to prevent the samples from being affected with moisture. Then, the samples were stored at $-20^{\circ} \mathrm{C}$ for future use.

Desulfo-glucosinolates (DS-GLSs) were extracted as previously described $[39,40]$. About $0.200 \mathrm{~g}$ powder was put into a $10 \mathrm{~mL}$ centrifuge tube, and $8 \mathrm{~mL} \mathrm{70 \%} \mathrm{methanol}$ solution preheated at $80^{\circ} \mathrm{C}$ was added into the centrifuge tube. After mixing, the tube was put into a water bath at $80^{\circ} \mathrm{C}$ for $10 \mathrm{~min}$, and mixed with intermittent oscillation. After $10 \mathrm{~min}, 1 \mathrm{~mL}$ barium acetate $(0.5 \mathrm{~mol} / \mathrm{L})$ was added to remove the soluble protein. After centrifugation at $5000 \mathrm{rpm}$ for $10 \mathrm{~min}$, the supernatant was removed and stored at $-20{ }^{\circ} \mathrm{C}$ for later use. For internal standard treatment, $100 \mu \mathrm{L}$ of 2-propenyl glucosinolate ( $5 \mathrm{mmol} / \mathrm{L}$, Sinigrin) were added to $0.200 \mathrm{~g}$ of dry sample powder. After mixing, $8 \mathrm{~mL} \mathrm{70 \%}$ methanol solution was preheated at $80^{\circ} \mathrm{C}$ immediately, and then extracted and further prepared according to the above method.

Next, $4 \mathrm{~mL}$ of the extract was passed through the column filled with $1 \mathrm{~cm}$ DEAE Sephadex A25 (Sigma, St. Louis, MO, USA) four times. After all the filtrate was drained, $1 \times 4 \mathrm{~mL}$ of sodium acetate buffer $(0.1 \mathrm{~mol} / \mathrm{L}, \mathrm{pH} 5)$ was added to clean the column. Finally, 
$200 \mu \mathrm{L}$ of sulfate esterase (Sigma) was added to the column. After reaction at $37^{\circ} \mathrm{C}$ for $18 \mathrm{~h}$, the eluent was eluted with $1 \times 4 \mathrm{~mL}$ ultra-pure water. The eluent was filtered by $0.22 \mu \mathrm{m}$ PTFE needle filter and stored at $-20{ }^{\circ} \mathrm{C}$ for detection and analysis.

\subsection{HPLC-MS Analysis of GLSs}

Determination: GLS separation was performed using Agilent Poroshell 120 EC-C18 reversed phase column (inner diameter $2.1 \times 100 \mathrm{~mm}$, particle diameter $=2.7 \mu \mathrm{m}$ ). Acidified water $(0.1 \%$ formic acid, $v / v)$ and acetonitrile $(0.1 \%$ formic acid, $v / v)$ were used as mobile phases $\mathrm{A}$ and $\mathrm{B}$, respectively. The gradient program was carried out as follows: $0-3 \min 97 \% \mathrm{~A}$ and $3 \% \mathrm{~B} ; 10 \mathrm{~min} 80 \% \mathrm{~A}$ and $20 \% \mathrm{~B} ; 13 \mathrm{~min} 20 \% \mathrm{~A}$ and $80 \% \mathrm{~B} ; 13.5-14 \mathrm{~min}$ $50 \% \mathrm{~A}$ and $50 \% \mathrm{~B} ; 15-16 \mathrm{~min} 97 \% \mathrm{~A}$ and $3 \% \mathrm{~B}$. The flow rate was set at $0.30 \mathrm{~mL} / \mathrm{min}$ throughout the gradient. The injection volume was $5 \mu \mathrm{L}$. The program was repeated three times for each sample, and the column temperature was maintained at $30^{\circ} \mathrm{C}$. The content of the glucosinolate components was calculated according to the international standardized response factor.

Mass spectrometry conditions: The Orbitrap high-resolution mass spectrometry was equipped with a suitable HESI source that was utilized with the following optimized parameter set: scan mode-full MS/AIF scan in positive ion mode; collision energy-35 eV; spray voltage $-3.7 \mathrm{kV}$; capillary temperature $-320^{\circ} \mathrm{C}$; auxiliary gas heater temperature$320^{\circ} \mathrm{C}$; sheath gas flow rate- 40 arb; auxiliary gas flow rate- 15 arb; sweep gas flow rate $-5 \mathrm{arb}$; the auxiliary gas, sheath gas and sweep gas were all high-purity nitrogen.

Quantitative and qualitative of glucosinolates: Separation and identification of different desulfo-glucosinolates of Chinese kale were performed by using HPLC according to their retention times and confirmed by LC-ESI-MS analysis. Identification of GLSs was carried out at the positive ion mode. The DS-GLSs were confirmed according to their $[\mathrm{M}-\mathrm{G}+\mathrm{H}]^{+},[\mathrm{M}+\mathrm{H}]^{+},[\mathrm{M}+\mathrm{Na}]^{+}$and $[\mathrm{M}+\mathrm{K}]^{+}$quasi-molecular ions and characteristic absorption peak [41]. The glucosinolate content was determined on the basis of retention time and peak area using sinigrin as an internal standard. The glucosinolate content was calculated using internal standard and response factors [42].

\subsection{Expression Analysis of Genes Involving in the Glucosinolate Biosynthesis}

According to instructions of the plant RNA extraction kit of Tiangen Biotech (Beijing, China) Co., LTD, the total RNA was extracted from the stems and leaves (the same growth material as the measurement of kale glucosinolate index) of the kale cultivars QB1 and $\mathrm{ZH}$ with high total glucosinolate content, and the low-glucosinolate content cultivars XLB and DSHH. Referring to CDNA sequences of Brassica MAMA1, SOT16 and other genes published in the NCBI database, the primers designed by Primer 5 for the expression detection of key genes in the glucosinolate biosynthesis pathway of Chinese kale are shown in Table 2, and the reference gene is Actin1 (XM_009117825.3). The expression levels of genes were detected by the real-time fluorescence quantitative method.

Table 2. Primers used in qRT-PCR reactions.

\begin{tabular}{|c|c|c|}
\hline Primer & Sequence $5^{\prime}-3^{\prime}$ & Reference Genes ID and Sources of Species \\
\hline Actin1 & F:5'-GGAATATGATGAGTCAGGCCC & \multirow{2}{*}{$\begin{array}{c}\text { XM_009117825.3 } \\
\text { Brassica rapa (field mustard) }\end{array}$} \\
\hline Actin1 & R:5'-CCCAGTAAGGATGAATTGGAAA & \\
\hline CYP83A1 & F:5'-GGTTCTCCTCTTCTTCCTCTCT & \multirow{2}{*}{$\begin{array}{c}\text { KM111290.1 } \\
\text { Brassica oleracea (wild cabbage) }\end{array}$} \\
\hline CYP83A1 & R:5'-CCACCATTGTTTGACTTCCTAT & \\
\hline MAM1 & F:5'-TATTTGATACGACGCTCCG & \multirow{2}{*}{$\begin{array}{c}\text { KP295465.1 } \\
\text { Brassica oleracea (wild cabbage) }\end{array}$} \\
\hline MAM1 & R:5'-CAACTTCCATGATGTCTACTCTG & \\
\hline UGT74B1 & F:5'-CCGAAACCTTAACCCGAGTA & \multirow{2}{*}{$\begin{array}{c}\text { KP693685.1 } \\
\text { Brassica oleracea var. italica }\end{array}$} \\
\hline UGT74B1 & R:5'-GTTGGTGAAGAAAGCAGCAG & \\
\hline
\end{tabular}


Table 2. Cont.

\begin{tabular}{|c|c|c|}
\hline Primer & Sequence $5^{\prime}-3^{\prime}$ & Reference Genes ID and Sources of Species \\
\hline SOT16 & F:5'-CTAATCCTTTGCCGTTTGTG & \multirow{2}{*}{$\begin{array}{c}\text { KP055788.1 } \\
\text { Brassica napus (rape) }\end{array}$} \\
\hline SOT16 & R:5'-CСТСССТСТССТТАТСТССТT & \\
\hline SOT17 & F:5'-AATAAAGGGGAGAAAGATAGGG & \multirow{2}{*}{$\begin{array}{c}\text { KP055792.1 } \\
\text { Brassica napus (rape) }\end{array}$} \\
\hline SOT17 & R:5'-TGAAGCAAGAAAGCCAGTT & \\
\hline SOT18 & F:5'-CCCAAAGACAGGCACCACTT & \multirow{2}{*}{$\begin{array}{c}\text { XM_013733021.1 } \\
\text { Brassica oleracea (wild cabbage) }\end{array}$} \\
\hline SOT18 & R:5'-GGAATCGTCGAAGCGAGATC & \\
\hline CYP83B1 & F:5'-AGACATCСССААТСТСССТT & \multirow{2}{*}{$\begin{array}{c}\text { AF528175.1 } \\
\text { Brassica rapa (field mustard) }\end{array}$} \\
\hline CYP83B1 & R:5'-CCACTCCTTTCTGCTCGTTC & \\
\hline CYP79A2 & F:5'-TGGCTAAAGACACCAACGG & \multirow{2}{*}{$\begin{array}{c}\text { EU877074.1 } \\
\text { Brassica rapa (field mustard) }\end{array}$} \\
\hline CYP79A2 & R:5'-CGAATACTACATGCTACACGCT & \\
\hline
\end{tabular}

\subsection{Statistical Analysis}

The SPSS 23.0 software package was used to process the data, and analysis of variance and Duncan multiple range tests were carried out at a 95\% confidence level.

\section{Results}

\subsection{Confirmation of Chinese Kale Desulfo-Glucosinolates}

As shown in Table 3, the $[\mathrm{M}-\mathrm{G}+\mathrm{H}]^{+}$and $[\mathrm{M}+\mathrm{H}]^{+}$characteristic ion fragments of desulphurization glucosinolates appeared in all glucosinolates under the impact of positive ion spray, while SIN did not detect this characteristic fragment in $\left[\mathrm{M}+\mathrm{Na}^{+}\right.$. GRA and SIN did not detect this characteristic fragment in $[\mathrm{M}+\mathrm{K}]^{+}$. The HPLC profile of glucosinolates in sixteen Chinese kale varieties indicate that eight glucosinolates were isolated and identified within $15 \mathrm{~min}$, including four A-GLSs (GRA, SIN, GNA and GER) and four indolyl GLSs (4-HGBS, GBS, 4-MGBS and NGBS), and aromatic GLSs (R-GLSs) were not found in this experiment (Figure 2).

Table 3. Glucosinolates identified in sixteen different Chinese kale varieties.

\begin{tabular}{|c|c|c|c|c|c|c|c|c|c|c|}
\hline \multirow{2}{*}{ No. ${ }^{a}$} & \multirow{2}{*}{$\begin{array}{l}\mathrm{RT}^{\mathrm{b}} \\
(\mathrm{min})\end{array}$} & \multirow{2}{*}{$\begin{array}{c}\text { Semi-Systematic } \\
\text { Names of } \\
\text { R-Groups } \\
\end{array}$} & \multirow{2}{*}{ Trivial Name } & \multirow{2}{*}{ Abbreviation } & \multirow{2}{*}{$\begin{array}{l}\text { Compound } \\
\text { Groups }\end{array}$} & \multicolumn{4}{|c|}{$\mathrm{m} / \mathrm{z}$ Value } & \multirow{2}{*}{$\begin{array}{l}\text { Response } \\
\text { Factor }^{\mathrm{d}}\end{array}$} \\
\hline & & & & & & {$[\mathbf{M}-\mathbf{G}+\mathbf{H}]^{+}$} & {$[\mathbf{M}+\mathbf{H}]^{+}$} & {$[\mathrm{M}+\mathrm{Na}]^{+}$} & {$[\mathbf{M}+\mathbf{K}]^{+}$} & \\
\hline 1 & 1.02 & $\begin{array}{l}4- \\
\text { methylsulphinylbutyl }\end{array}$ & Glucoraphanin & GRA & Aliphatic & 196.0455 & 258.0968 & 380.0801 & $\mathrm{ND}^{\mathrm{c}}$ & 1.07 \\
\hline 2 & 1.03 & 2-propenyl & Sinigrin & $\mathrm{SIN}$ & Aliphatic & 118.0319 & 280.0841 & ND & ND & 1.00 \\
\hline 3 & 1.32 & 3-butenyl & Gluconapin & GNA & Aliphatic & 132.0472 & 294.0992 & 316.0811 & 332.0549 & 1.11 \\
\hline 4 & 3.06 & $\begin{array}{l}\text { 4-hydroxy-3- } \\
\text { indolylmethyl }\end{array}$ & $\begin{array}{l}\text { 4-Hydroxyglu } \\
\text { cobrassicin }\end{array}$ & 4-HGBS & Indolyl & 223.0528 & 385.1051 & 407.0870 & 423.0816 & 0.28 \\
\hline 5 & 8.19 & 4-methylthiobutyl & Glucoerucin & GER & Aliphatic & 180.0503 & 342.1025 & 364.0841 & 380.0789 & 1.00 \\
\hline 6 & 9.16 & 3-methylindolyl & Glucobrassicin & GBS & Indolyl & 207.0578 & 369.1098 & 391.0916 & 407.0657 & 0.29 \\
\hline 7 & 10.60 & $\begin{array}{l}\text { 4-methoxy-3- } \\
\text { indolylmethyl }\end{array}$ & $\begin{array}{l}\text { 4-Methoxyglu } \\
\text { cobrassicin }\end{array}$ & 4-MGBS & Indolyl & 237.0682 & 399.1205 & 421.1022 & 437.0761 & 0.25 \\
\hline 8 & 12.58 & $\begin{array}{l}\text { 1-methoxy-3- } \\
\text { indolylmethyl }\end{array}$ & Neoglucobrassincin & NGBS & Indolyl & 237.0682 & 399.1205 & 421.1022 & 437.0763 & 0.20 \\
\hline
\end{tabular}

${ }^{a}$ No., the elution order of glucosinolates from HPLC chromatograms in Figure $1 .{ }^{b}$ RT, retention time. ${ }^{c}$ ND, not detected. ${ }^{\mathrm{d}}$ International Organization for Standardization (ISO 9167-1, 1992). 


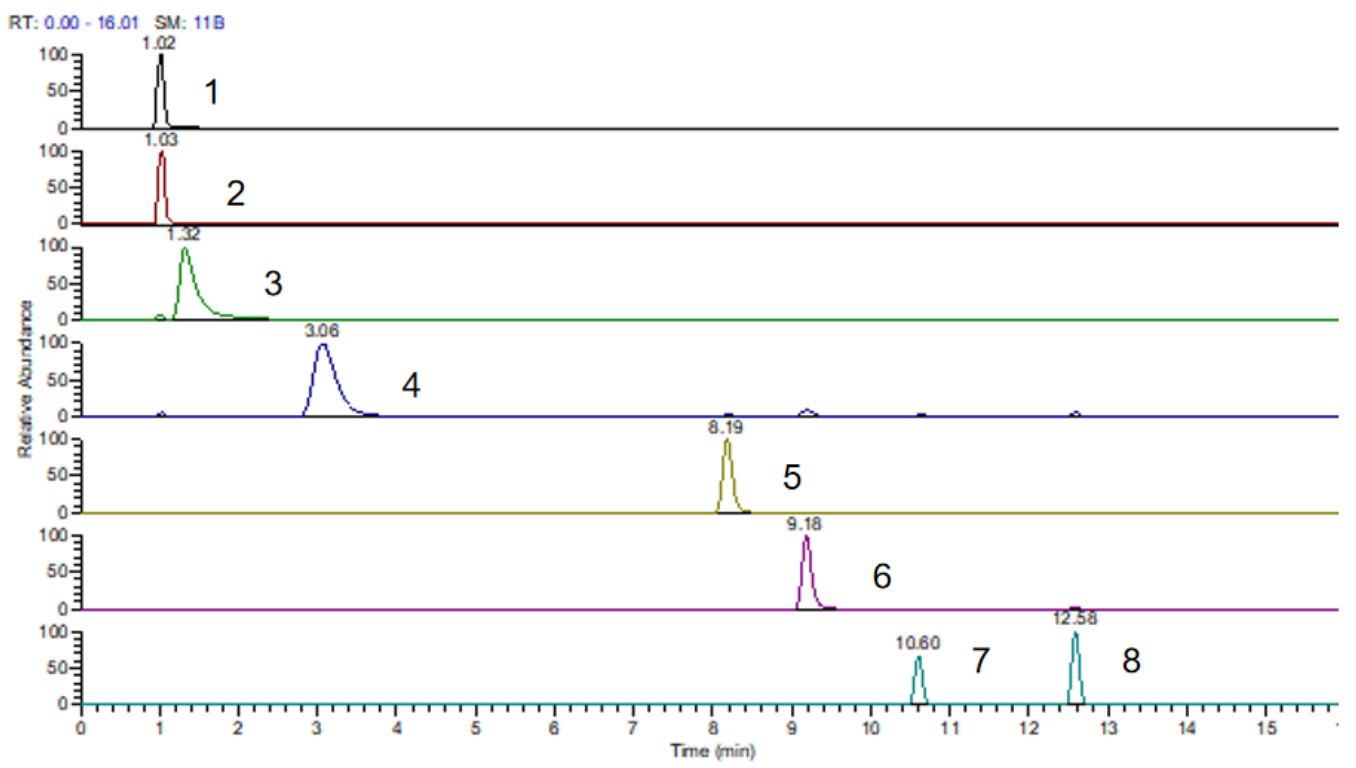

Figure 2. HPLC chromatogram of glucosinolates (GLSs) isolated from kale varieties. Peak numbers refer to the GLSs listed in Table 3. Peak no. 1,.Glucoraphanin(GRA); 2, sinigrin(SIN); 3, Gluconapin(GNA); 4, 4-Hydroxyglucobrassicin(4-HGBS); 5, Glucoerucin(GER); 6, Glucobrassicin(GBS); 7, 4-Methoxyglucobrassicin(4-MGBS); 8, Neoglucobrassincin(NGBS).

3.2. The Content and Component Analysis of GLSs in Edible Stems and Leaves of Sixteen Chinese Kale Varieties

As shown in Figure 3a, the contents of aliphatic glucosinolate (A-GLSs) in the stems of Chinese kale varieties ranged from 238.27 to $1079.65 \mu \mathrm{mol} / 100 \mathrm{~g} \mathrm{DW}$ (the average was $490.03 \mu \mathrm{mol} / 100 \mathrm{~g}$ DW). The contents of A-GLSs in the stems of Japanese kale varieties QB1 and Chinese kale varieties ZH were $1079.65 \mu \mathrm{mol} / 100 \mathrm{~g}$ DW and 780.29 $\mu \mathrm{mol} / 100 \mathrm{~g} \mathrm{DW}$, respectively, which were significantly higher than those of other varieties, and there was a very significant difference between them. The A-GLSs content in leaves of different Chinese kale varieties ranged from 47.12 to $1179.2 \mu \mathrm{mol} / 100 \mathrm{~g}$ DW (the average content was $427.77 \mu \mathrm{mol} / 100 \mathrm{~g} \mathrm{DW})$, and the A-GLSs content in leaves of Japanese variety QB1 was significantly higher than $985.56 \mu \mathrm{mol} / 100 \mathrm{~g}$ DW of QB2. The A-GLSs content of QB2 was significantly higher than that of XLB and $\mathrm{ZH}$, which ranked third and fourth and were significantly higher than other varieties. The content of A-GLSs in stems and leaves of the Japanese variety XLB was the lowest. In addition, except for the content of A-GLSs in stems of varieties SB, XL, XLB, DB and SJT being significantly higher than that in leaves, there was little difference in the content of A-GLSs in stems and leaves of most varieties.

The accumulation of indole glucosinolate (I-GLSs) in the stems of various kale varieties ranged from 22.5 to $67.09 \mu \mathrm{mol} / 100 \mathrm{~g}$ DW (average $35.61 \mu \mathrm{mol} / 100 \mathrm{~g} \mathrm{DW}$ ); the content of I-GLSs in the stem of variety KDSJ was $67.09 \mu \mathrm{mol} / 100 \mathrm{~g} \mathrm{DW}$, significantly higher than other varieties (Figure 3b). In leaves, the accumulation of I-GLSs was 10.73 to $87.13 \mu \mathrm{mol} / 100 \mathrm{~g}$ DW (average $45.95 \mu \mathrm{mol} / 100 \mathrm{~g}$ DW), the content of I-GLSs in the leaves of variety KDSJ was as high as $87.13 \mu \mathrm{mol} / 100 \mathrm{~g} \mathrm{DW}$, significantly higher than that of other varieties, and the content of varieties $\mathrm{DB}$ and $\mathrm{XLB}$ was lower. Except $\mathrm{CB}, \mathrm{XB}, \mathrm{DB}$ and XLB, the accumulation of I-GLSs in the leaves was higher than that in the stems or had little difference. Overall, the content of total I-GLSs in the stems and leaves of variety KDSJ was the highest, and the accumulation of total I-GLSs in variety DB was the lowest (Figure 3b).

The content of total glucosinolates (T-GLSs) ranged from 399.3 to $2346.03 \mu \mathrm{mol} / 100 \mathrm{~g}$ DW (with an average of $1005.41 \mu \mathrm{mol} / 100 \mathrm{~g} \mathrm{DW}$ ), and the highest content was found in Japanese variety QB1. Japanese variety QB2 and Chinese variety ZH had T-GLS content of $1665.54 \mu \mathrm{mol} / 100 \mathrm{~g}$ DW and $1649.49 \mu \mathrm{mol} / 100 \mathrm{~g}$ DW, respectively, and there was no significant difference in contents. The content of QB1 T-GLSs was significantly higher than that of ZH and QB2, and the latter was significantly higher than that of other varieties, while the 
content of XLB T-GLSs was the lowest. Further analysis showed that the content of A-GLSs in T-GLSs accounted for $80.69 \%$ to $96.28 \%$ (average $90.50 \%$ ) and was the main component. The total glucosinolates content in stem ranged from 267.38 to $1104.32 \mu \mathrm{mol} / 100 \mathrm{~g} \mathrm{DW}$, and in leaf it ranged from 57.87 to $1241.71 \mu \mathrm{mol} / 100 \mathrm{~g}$ DW. The T-GLSs content in stem was higher than that in leaf except for varieties LB, QB1, QB2, YC, DSHH and ZH (Figure 3c).
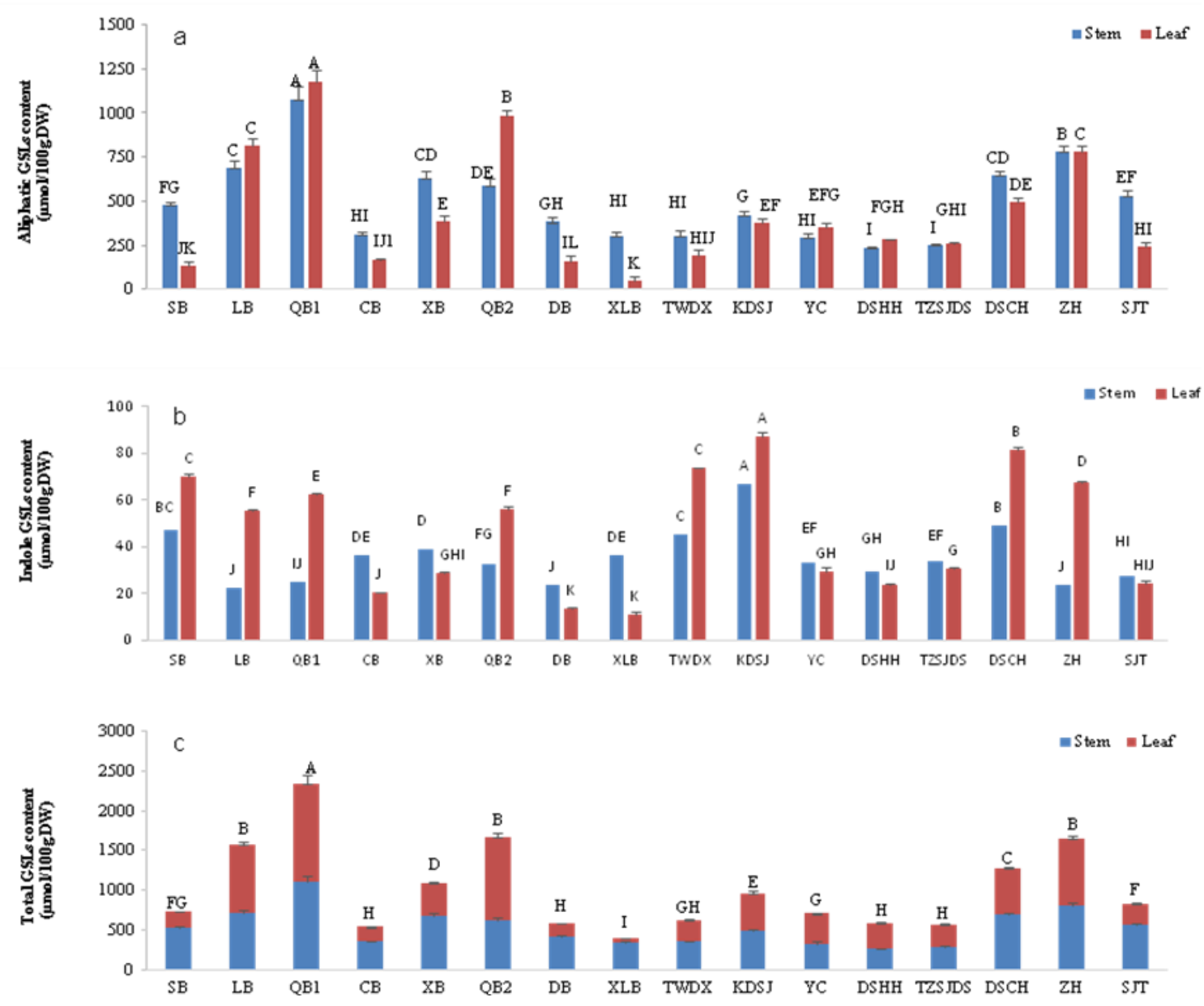

Figure 3. Accumulation of aliphatic, indole and total glucosinolates in stems and leaves of sixteen Chinese kale varieties. Different capital letters indicate extremely significant differences $(p<0.01)$. (a) Aliphatic glucosinolate content; (b) indole glucosinolate content; (c) total glucosinolate content.

\subsection{Analysis of GLSs Components and Contents in Edible Leaves of Chinese Kale Varieties}

Three aliphatic glucosinolates, GRA, SIN and GNA, and four indole glucosinolates, 4HGBS, GBS, 4-MGBS and NGBS, appeared in the edible leaves of 16 Chinese kale varieties, and the contents of GER in the leaves of different varieties were different. GER was not detected in half of the leaves from Japanese kale, but existed in Chinese kale leaves (Table 4). The contents of GRA and GNA in A-GLSs ranged from $1.63 \%$ to $82.82 \%$ (33.08\% on average) and $15.76 \%$ to $94.28 \%$ (61.86\% on average), respectively, representing the main components of A-GLSs in the edible leaves of various Chinese kale varieties. Except DSHH, the content of GRA exceeds $100 \mu \mathrm{mol} / 100 \mathrm{~g}$ DW in the leaves of Chinese kale varieties from China, and DSCH and SJT are 211.83 and $201.88 \mu \mathrm{mol} / 100 \mathrm{~g}$ DW, respectively, significantly higher than that of other tested Chinese varieties. The GRA content in edible leaves of Japanese varieties XB and QB2 was higher than $100 \mu \mathrm{mol} / 100 \mathrm{~g} \mathrm{DW}$, but lower than $70 \mu \mathrm{mol} / 100 \mathrm{~g}$ DW in other varieties. On the contrary, high content of GNA mostly appeared in the leaves of Japanese varieties. For example, the GNA contents of QB1 and QB2 were 1077.68 and $809.65 \mu \mathrm{mol} / 100 \mathrm{~g}$ DW, respectively, which was significantly higher than that of other 
varieties. The GNA content in the leaves of the Chinese kale variety $\mathrm{ZH}$ was the highest, reaching $629.1 \mu \mathrm{mol} / 100 \mathrm{~g}$ DW. The content of SIN in Chinese kale edible leaves ranged from 1.59 to $39.6 \mu \mathrm{mol} / 100 \mathrm{~g} \mathrm{DW}$, with the highest content in DSHH varieties and the lowest in TZSJDS varieties. The content of GER in all detected varieties was less than $1 \mu \mathrm{mol} / 100 \mathrm{~g}$ DW.

Table 4. Composition and accumulation of glucosinolates $\left(\mu \mathrm{mol} / 100 \mathrm{~g} \mathrm{DW}^{\mathrm{a}}\right)$ in the edible leaves of 16 varieties of Chinese kale.

\begin{tabular}{|c|c|c|c|c|c|c|c|c|}
\hline \multirow{2}{*}{$\begin{array}{l}\text { Abbreviation } \\
\text { of Chinese } \\
\text { Kale Varieties }\end{array}$} & \multicolumn{4}{|c|}{ Aliphatic Glucosinolates } & \multicolumn{4}{|c|}{ Indole Glucosinolates } \\
\hline & GRA & SIN & GNA & GER & 4-HGBS & GBS & 4-MGBS & NGBS \\
\hline SB & $55.02 \pm 2.96 \mathrm{~F}$ & $11.5 \pm 0.43 \mathrm{~F}$ & $67.11 \pm 5.55 \mathrm{G}$ & $\mathrm{ND}^{\mathrm{b}}$ & $1.74 \pm 0.12 \mathrm{~B}$ & $65.61 \pm 2.71 \mathrm{~B}$ & $2.18 \pm 0.09 \mathrm{IJ}$ & $0.66 \pm 0.07 \mathrm{DE}$ \\
\hline LB & $13.29 \pm 1.2 \mathrm{G}$ & $33.1 \pm 1.22 \mathrm{~B}$ & $\begin{array}{c}764.74 \pm \\
22.41 \mathrm{~B}\end{array}$ & ND & $0.74 \pm 0.03 \mathrm{D}$ & $50.51 \pm 1.89 \mathrm{D}$ & $\begin{array}{c}4.02 \pm \\
0.11 \mathrm{DEF}\end{array}$ & $0.38 \pm 0.02 \mathrm{EF}$ \\
\hline QB1 & $63.93 \pm 2.92 F$ & $37.53 \pm 1.43 \mathrm{~A}$ & $\begin{array}{c}1077.68 \pm \\
96.73 \mathrm{~A}\end{array}$ & $\begin{array}{c}0.081 \pm \\
0.003 \mathrm{CDE}\end{array}$ & $2.43 \pm 0.22 \mathrm{~A}$ & $\begin{array}{l}55.49 \pm \\
2.55 \mathrm{DE}\end{array}$ & $\begin{array}{c}4.06 \pm \\
0.25 \mathrm{DEF}\end{array}$ & $0.51 \pm 0.06 \mathrm{EF}$ \\
\hline CB & $49.64 \pm 2.94 \mathrm{~F}$ & $10.21 \pm 0.95 \mathrm{FG}$ & $\begin{array}{l}104.56 \pm \\
6.45 \mathrm{EFG}\end{array}$ & $0.001 \pm 0.001 \mathrm{E}$ & $0.74 \pm 0.03 \mathrm{D}$ & $17.92 \pm 0.55 \mathrm{~F}$ & $1.47 \pm 0.06 \mathrm{~K}$ & $0.11 \pm 0.01 \mathrm{~F}$ \\
\hline $\mathrm{XB}$ & $\begin{array}{c}110.08 \pm \\
10.46 \mathrm{E}\end{array}$ & $11.7 \pm 0.77 \mathrm{~F}$ & $\begin{array}{c}264.32 \pm \\
18.79 \mathrm{D}\end{array}$ & $\begin{array}{l}0.061 \pm \\
0.002 \mathrm{DE}\end{array}$ & $0.77 \pm 0.01 \mathrm{D}$ & $24.64 \pm 0.52 \mathrm{E}$ & $2.9 \pm 0.29 \mathrm{GH}$ & $0.18 \pm 0.02 \mathrm{~F}$ \\
\hline QB2 & $\begin{array}{c}149.25 \pm \\
8.33 \mathrm{BC}\end{array}$ & $26.36 \pm 1.63 C$ & $\begin{array}{c}809.65 \pm \\
49.64 \mathrm{~B}\end{array}$ & $0.291 \pm 0.218 \mathrm{~B}$ & $2.34 \pm 0.1 \mathrm{~A}$ & $50.01 \pm 1.33 \mathrm{D}$ & $3.62 \pm 0.35 \mathrm{EF}$ & $0.2 \pm 0.01 \mathrm{~F}$ \\
\hline $\mathrm{DB}$ & $22.07 \pm 1.93 \mathrm{G}$ & $20.84 \pm 0.74 \mathrm{D}$ & $\begin{array}{l}119.36 \pm \\
6.78 \mathrm{EFG}\end{array}$ & ND & $0.2 \pm 0.01 \mathrm{~F}$ & $8.76 \pm 0.48 \mathrm{G}$ & $\begin{array}{c}4.49 \pm \\
0.22 \mathrm{BCD}\end{array}$ & $0.24 \pm 0.01 \mathrm{~F}$ \\
\hline XLB & $10.48 \pm 0.36 \mathrm{G}$ & $3.22 \pm 0.1 \mathrm{IJ}$ & $33.42 \pm 1.72 \mathrm{G}$ & ND & $0.21 \pm 0.01 \mathrm{~F}$ & $8.85 \pm 0.3 G$ & $1.62 \pm 0.23 \mathrm{JK}$ & $0.08 \pm 0.01 \mathrm{~F}$ \\
\hline TWDX & $\begin{array}{c}137.26 \pm \\
4.72 \mathrm{CD}\end{array}$ & $5.54 \pm 0.77 \mathrm{HI}$ & $49.98 \pm 12.76 \mathrm{G}$ & $\begin{array}{c}0.12 \pm \\
0.004 \mathrm{BCDE}\end{array}$ & $0.67 \pm 0.09 \mathrm{DE}$ & $67.25 \pm 1.81 \mathrm{~B}$ & $3.82 \pm 0.07 \mathrm{EF}$ & $1.82 \pm 0.11 C$ \\
\hline KDSJ & $169.12 \pm 4.07 \mathrm{~B}$ & $17.19 \pm 0.45 C$ & $\begin{array}{c}190.52 \pm \\
27.65 \mathrm{DEF}\end{array}$ & $\begin{array}{c}0.235 \pm \\
0.012 B C D\end{array}$ & $1.69 \pm 0.06 \mathrm{~B}$ & $77.36 \pm 0.61 \mathrm{~A}$ & $4.74 \pm 0.17 \mathrm{BC}$ & $3.34 \pm 0.35 \mathrm{~B}$ \\
\hline YC & $\begin{array}{l}118.52 \pm \\
9.43 \mathrm{DE}\end{array}$ & $8.28 \pm 0.68 \mathrm{GH}$ & $222.29 \pm 9.23 \mathrm{D}$ & $\begin{array}{c}0.092 \pm \\
0.002 \mathrm{CDE}\end{array}$ & $0.58 \pm 0.03 \mathrm{DE}$ & $22 \pm 0.78 \mathrm{EF}$ & $5.57 \pm 0.13 \mathrm{~A}$ & $0.97 \pm 0.14 \mathrm{D}$ \\
\hline DSHH & $49.74 \pm 4.11 \mathrm{~F}$ & $39.6 \pm 1.58 \mathrm{~A}$ & $\begin{array}{l}194.48 \pm \\
22.61 \mathrm{DE}\end{array}$ & ND & $0.45 \pm 0.03 \mathrm{E}$ & $18.95 \pm 0.71 \mathrm{~F}$ & $4.1 \pm 0.08 \mathrm{DE}$ & $0.13 \pm 0.01 \mathrm{~F}$ \\
\hline TZSJDS & $\begin{array}{c}161.04 \pm \\
9.01 \mathrm{BC}\end{array}$ & $1.59 \pm 0.05 \mathrm{~J}$ & $\begin{array}{l}92.82 \pm \\
10.98 \mathrm{FG}\end{array}$ & $0.868 \pm 0.047 \mathrm{~A}$ & $0.66 \pm 0.07 \mathrm{DE}$ & $25.75 \pm 0.51 \mathrm{E}$ & $3.41 \pm 0.31 \mathrm{FG}$ & $0.68 \pm 0.06 \mathrm{DE}$ \\
\hline $\mathrm{DSCH}$ & $\begin{array}{c}211.83 \pm \\
14.51 \mathrm{~A}\end{array}$ & $15.72 \pm 1.84 \mathrm{E}$ & $\begin{array}{c}265.72 \pm \\
19.78 \mathrm{D}\end{array}$ & $\begin{array}{l}0.265 \pm \\
0.011 \mathrm{BC}\end{array}$ & $0.78 \pm 0.01 \mathrm{D}$ & $64.93 \pm 4.14 \mathrm{~B}$ & $5.01 \pm 0.05 \mathrm{AB}$ & $10.75 \pm 0.31 \mathrm{~A}$ \\
\hline $\mathrm{ZH}$ & $\begin{array}{c}120.01 \pm \\
2.16 \mathrm{DE}\end{array}$ & $28.5 \pm 0.77 C$ & $629.1 \pm 41.2 C$ & $\begin{array}{l}0.072 \pm \\
0.004 \mathrm{DE}\end{array}$ & $1.14 \pm 0.02 \mathrm{C}$ & $62.26 \pm 1.8 \mathrm{~B}$ & $2.61 \pm 0.24 \mathrm{HI}$ & $1.63 \pm 0.09 \mathrm{C}$ \\
\hline SJT & $\begin{array}{c}201.88 \pm \\
16.00 \mathrm{~A}\end{array}$ & $3.19 \pm 0.21 \mathrm{IJ}$ & $38.41 \pm 6.82 \mathrm{G}$ & $0.265 \pm 0.05 \mathrm{BC}$ & $0.67 \pm 0.07 \mathrm{DE}$ & $18.49 \pm 0.42 \mathrm{~F}$ & $\begin{array}{c}4.26 \pm \\
0.27 \mathrm{CDE}\end{array}$ & $1.08 \pm 0.02 \mathrm{D}$ \\
\hline
\end{tabular}

Different capital letters indicate extremely significant difference $(p<0.01)$. Mean $\pm \mathrm{SE},(n=3) .{ }^{\text {a DW, dry weight. }}{ }^{\mathrm{b}} \mathrm{ND}$, not detected.

Among indole glucosinolate, the content of GBS in leaves of Chinese kale varieties ranged from 8.76 to $77.36 \mu \mathrm{mol} / 100 \mathrm{~g}$ DW, and the GBS content of KDSJ was significantly higher than that of other varieties, while the contents of SB, TWDX, DSCH and ZH were not significantly different. The content of 4-MGBS ranged from 1.47 to $5.57 \mu \mathrm{mol} / 100 \mathrm{~g}$ DW. The contents of other components 4-HGBS and NGBS were all low.

\subsection{Analysis of GLSs Components and Contents in Edible Stems of Chinese Kale Varieties}

Different from the edible leaves, eight kinds of glucosinolates were detected in the edible stems of sixteen Chinese kale varieties. Similar to the leaves, GRA and GNA were also the main components of A-GLSs in the stems, with GRA accounting for $3.20 \%$ to $21.49 \% \%$ (average $17.67 \%$ ) and GNA accounting for $31.42 \%$ to $90.08 \%$ (average $58.45 \%$ ) (Table 5). The content of GRA in the stems of all Chinese kale varieties ranged from 63.49 to $201.05 \mu \mathrm{mol} / 100 \mathrm{~g}$ DW. Among them, the Chinese variety SJT and the Japanese variety SB had the highest GRA content, and the difference between the two was not significant, but their GRA contents were significantly higher than that of other varieties. The GRA contents were the lowest in Japanese variety LB and QB1 and the GRA content of Chinese varieties was generally higher than that of Japanese varieties in the stems. The GNA contents in the stems of each varieties were significantly different, and the average accumulation was $324.33 \mu \mathrm{mol} / 100 \mathrm{~g}$ DW, in which the GNA contents of LB, QB1 and ZH varieties were higher than $500 \mu \mathrm{mol} / 100 \mathrm{~g}$ DW, significantly higher than other varieties. The content of SIN ranged from 1.28 to $43.18 \mu \mathrm{mol} / 100 \mathrm{~g}$ DW, and the content of Japanese varieties was mostly higher than that of Chinese varieties in the stems. The content of GER in stem 
ranged from $2.28 \mu \mathrm{mol} / 100 \mathrm{~g} \mathrm{DW}$ to $27.47 \mu \mathrm{mol} / 100 \mathrm{~g} \mathrm{DW}$, and the average content was about 80 times higher than that in leaf, but GER accounted for a small proportion of A-GLSs in stems and leaves.

Table 5. Composition and accumulation of glucosinolates ( $\mu \mathrm{mol} / 100 \mathrm{~g} \mathrm{DW})$ in the edible stems of 16 varieties of Chinese kale.

\begin{tabular}{|c|c|c|c|c|c|c|c|c|}
\hline \multirow{2}{*}{$\begin{array}{l}\text { Abbreviation } \\
\text { of Chinese } \\
\text { Kale Varieties }\end{array}$} & \multicolumn{4}{|c|}{ Aliphatic Glucosinolates } & \multicolumn{4}{|c|}{ Indole Glucosinolates } \\
\hline & GRA & SIN & GNA & GER & 4-HGBS & GBS & 4-MGBS & NGBS \\
\hline SB & $\begin{array}{c}194.34 \pm \\
11.38 \mathrm{ABC}\end{array}$ & $\begin{array}{l}21.56 \pm \\
2.12 \mathrm{DE}\end{array}$ & $\begin{array}{l}246.47 \pm \\
10.75 \mathrm{DE}\end{array}$ & $13.23 \pm 0.62 \mathrm{FG}$ & $7.2 \pm 0.11 \mathrm{~A}$ & $34.28 \pm 1.05 \mathrm{~B}$ & $\begin{array}{c}3.72 \pm \\
0.08 \mathrm{EFG}\end{array}$ & $2.06 \pm 0.32 \mathrm{C}$ \\
\hline LB & $63.49 \pm 4.21 \mathrm{I}$ & $36.7 \pm 4.68 \mathrm{AB}$ & $\begin{array}{c}587.66 \pm \\
45.52 \mathrm{~B}\end{array}$ & $2.28 \pm 0.22 \mathrm{~J}$ & $1.84 \pm 0.03 \mathrm{~F}$ & $\begin{array}{l}17.32 \pm \\
0.34 \mathrm{GH}\end{array}$ & $2.76 \pm 0.23 \mathrm{I}$ & $0.58 \pm 0.11 \mathrm{~F}$ \\
\hline QB1 & $74.97 \pm 3.76 \mathrm{I}$ & $29.43 \pm 2.35 B C$ & $\begin{array}{c}972.53 \pm \\
61.82 \mathrm{~A}\end{array}$ & $2.71 \pm 0.2 \mathrm{~J}$ & $1.76 \pm 0.07 \mathrm{~F}$ & $\begin{array}{l}17.45 \pm \\
0.31 \mathrm{GH}\end{array}$ & $\begin{array}{c}4.56 \pm \\
0.17 \mathrm{BCD}\end{array}$ & $0.91 \pm 0.06 \mathrm{EF}$ \\
\hline CB & $\begin{array}{l}138.08 \pm \\
8.23 \mathrm{EFG}\end{array}$ & $15.83 \pm 0.66 \mathrm{EF}$ & $\begin{array}{l}151.6 \pm \\
14.11 \mathrm{FG}\end{array}$ & $8.46 \pm 0.46 \mathrm{H}$ & $5.51 \pm 0.17 \mathrm{BC}$ & $25.69 \pm 0.21 \mathrm{D}$ & $\begin{array}{c}3.23 \pm \\
0.21 \mathrm{FGHI}\end{array}$ & $1.72 \pm 0.19 \mathrm{CD}$ \\
\hline $\mathrm{XB}$ & $\begin{array}{c}162 \pm \\
10.81 \mathrm{CDEF}\end{array}$ & $33.86 \pm 1.62 \mathrm{~B}$ & $\begin{array}{c}429.69 \pm \\
24.86 \mathrm{C}\end{array}$ & $7.34 \pm 0.2 \mathrm{H}$ & $4.75 \pm 0.13 \mathrm{C}$ & $31.9 \pm 0.57 \mathrm{C}$ & $2.04 \pm 0.07 \mathrm{~J}$ & $0.5 \pm 0.01 \mathrm{~F}$ \\
\hline QB2 & $\begin{array}{c}130.96 \pm \\
7.38 \mathrm{EF}\end{array}$ & $35.13 \pm 4.81 \mathrm{~B}$ & $\begin{array}{c}417.33 \pm \\
35.59 \mathrm{C}\end{array}$ & $8.19 \pm 0.18 \mathrm{H}$ & $3.14 \pm 0.15 \mathrm{E}$ & $23.19 \pm 0.65 \mathrm{E}$ & $4.6 \pm 0.18 \mathrm{BCD}$ & $1.3 \pm 0.05 \mathrm{DE}$ \\
\hline DB & $\begin{array}{l}90.47 \pm \\
11.13 \mathrm{HI}\end{array}$ & $43.18 \pm 5.41 \mathrm{~A}$ & $\begin{array}{l}244.07 \pm \\
23.02 \mathrm{DE}\end{array}$ & $4.76 \pm 0.25 \mathrm{I}$ & $3.38 \pm 0.17 \mathrm{DE}$ & $15.48 \pm 0.49 \mathrm{H}$ & $\begin{array}{c}3.59 \pm \\
0.14 \mathrm{EFGH}\end{array}$ & $1.28 \pm 0.14 \mathrm{DE}$ \\
\hline XLB & $\begin{array}{c}125.72 \pm \\
11.69 \mathrm{FGH}\end{array}$ & $15.88 \pm 0.8 \mathrm{EF}$ & $\begin{array}{l}156.14 \pm \\
21.34 \mathrm{FG}\end{array}$ & $7.55 \pm 0.36 \mathrm{H}$ & $4.9 \pm 1.21 C$ & $26.64 \pm 0.33 \mathrm{D}$ & $2.84 \pm 0.13 \mathrm{HI}$ & $1.76 \pm 0.1 C D$ \\
\hline TWDX & $\begin{array}{l}147.53 \pm \\
4.14 \mathrm{DEF}\end{array}$ & $9.46 \pm 0.52 \mathrm{FG}$ & $\begin{array}{c}128.96 \pm \\
7.87 \mathrm{FG}\end{array}$ & $17.22 \pm 0.61 \mathrm{BC}$ & $4.3 \pm 0.31 \mathrm{CDE}$ & $30.48 \pm 0.79 \mathrm{C}$ & $\begin{array}{c}3.82 \pm \\
0.02 \mathrm{DEF}\end{array}$ & $6.58 \pm 0.21 \mathrm{~A}$ \\
\hline KDSJ & $\begin{array}{c}179.08 \pm \\
11.23 \mathrm{BCD}\end{array}$ & $29.69 \pm 2.02 B C$ & $\begin{array}{c}202.29 \pm \\
11.04 \mathrm{EF}\end{array}$ & $12.02 \pm 0.49 \mathrm{G}$ & $6.23 \pm 0.59 \mathrm{AB}$ & $52.78 \pm 1.31 \mathrm{~A}$ & $\begin{array}{c}4.11 \pm \\
0.12 \mathrm{CDE}\end{array}$ & $3.97 \pm 0.06 \mathrm{~B}$ \\
\hline YC & $\begin{array}{c}152.03 \pm \\
14.14 \mathrm{DEF}\end{array}$ & $8.61 \pm 0.59 \mathrm{FG}$ & $\begin{array}{l}114.62 \pm \\
15.38 \mathrm{FG}\end{array}$ & $\begin{array}{l}16.51 \pm \\
0.21 C D\end{array}$ & $6.22 \pm 0.61 \mathrm{AB}$ & $19.98 \pm 0.77 \mathrm{~F}$ & $4.8 \pm 0.29 \mathrm{BC}$ & $2.27 \pm 0.6 \mathrm{C}$ \\
\hline DSHH & $\begin{array}{l}124.92 \pm \\
7.39 \mathrm{FGH}\end{array}$ & $\begin{array}{l}24.67 \pm \\
1.81 C D\end{array}$ & $74.86 \pm 7.65 G$ & $13.81 \pm 0.37 \mathrm{EF}$ & $\begin{array}{c}4.35 \pm \\
0.33 C E D\end{array}$ & $19.82 \pm 0.46 \mathrm{~F}$ & $\begin{array}{c}3.66 \pm \\
0.21 \mathrm{EFG}\end{array}$ & $1.29 \pm 0.08 \mathrm{DE}$ \\
\hline TZSJDS & $\begin{array}{l}127.82 \pm \\
13.13 \mathrm{FG}\end{array}$ & $1.28 \pm 0.1 \mathrm{G}$ & $105.33 \pm 7.97 \mathrm{G}$ & $\begin{array}{l}15.27 \pm \\
0.24 \mathrm{DE}\end{array}$ & $4.6 \pm 0.11 C D$ & $\begin{array}{l}24.84 \pm \\
0.32 \mathrm{DE}\end{array}$ & $\begin{array}{c}2.92 \pm \\
0.57 \mathrm{GHI}\end{array}$ & $1.61 \pm 0.09 \mathrm{CD}$ \\
\hline $\mathrm{DSCH}$ & $\begin{array}{c}173.57 \pm \\
8.03 \mathrm{BCDE}\end{array}$ & $33.52 \pm 4.16 \mathrm{~B}$ & $424.22 \pm 25.7 \mathrm{C}$ & $\begin{array}{l}15.62 \pm \\
0.61 C D\end{array}$ & $5.18 \pm 0.24 \mathrm{BC}$ & $34.77 \pm 1.31 \mathrm{~B}$ & $4.99 \pm 0.35 \mathrm{~B}$ & $3.95 \pm 0.24 \mathrm{~B}$ \\
\hline $\mathrm{ZH}$ & $\begin{array}{l}109.96 \pm \\
12.88 \mathrm{GH}\end{array}$ & $\begin{array}{l}19.91 \pm \\
0.55 \mathrm{DE}\end{array}$ & $633.92 \pm 50.2 B$ & $\begin{array}{l}16.49 \pm \\
0.54 \mathrm{CD}\end{array}$ & $1.47 \pm 0.03 \mathrm{~F}$ & $9.84 \pm 0.16 \mathrm{I}$ & $6.34 \pm 0.19 \mathrm{~A}$ & $6.2 \pm 0.17 \mathrm{~A}$ \\
\hline SJT & $\begin{array}{l}201.05 \pm \\
16.52 \mathrm{AB}\end{array}$ & $3.57 \pm 0.13 G$ & $\begin{array}{c}299.54 \pm \\
10.45 \mathrm{D}\end{array}$ & $27.47 \pm 0.69 \mathrm{~A}$ & $4.57 \pm 0.07 \mathrm{CD}$ & $18.02 \pm 0.34 \mathrm{FG}$ & $\begin{array}{c}3.03 \pm \\
0.36 \mathrm{FGHI}\end{array}$ & $1.72 \pm 0.18 \mathrm{CD}$ \\
\hline
\end{tabular}

Different capital letters indicate extremely significant difference $(p<0.01)$. Mean $\pm \mathrm{SE},(n=3) .{ }^{\mathrm{a}} \mathrm{DW}, \mathrm{dry}$ weight. ${ }^{\mathrm{b}} \mathrm{ND}$, not detected.

The content of GBS in the stems of various varieties of Chinese kale ranged from 9.76 to $52.78 \mu \mathrm{mol} / 100 \mathrm{~g}$ DW, accounting for a relatively high proportion in I-GLSs, and the content ranges of 4-HGBS and 4-MGBS are 1.47-7.20 and 0.50-6.58 $\mu \mathrm{mol} / 100 \mathrm{~g}$ DW, respectively. The 4-MGBS content of the $\mathrm{ZH}$ variety was significantly higher than that of other varieties. The content of NGBS in stems was higher than that in leaves, but the content was very low.

\subsection{Expression Analysis of Key Genes in GLSs Biosynthesis Pathway}

The QB1 and ZH varieties with higher total glucosinolate content and the low-content XLB and DSHH varieties were selected from Japanese and Chinese varieties, and the GLSs biosynthetic gene expressions were analyzed. As shown in Figure $4 \mathrm{~d}-\mathrm{g}$, the expression levels of aliphatic glucosinolate biosynthesis genes MAM1, CYP83A1, SOT17 and SOT18 were basically consistent with the changes in glucosinolate content; that is, the expression levels of these genes in high glucosinolate varieties were significantly higher than those in low glucosinolate varieties. In the same stem and leaf of the same variety, the relative expression level of CYP83A1 was more than 10 times that of MAM1, while the relative expression of SOT17 and SOT18 was low. 

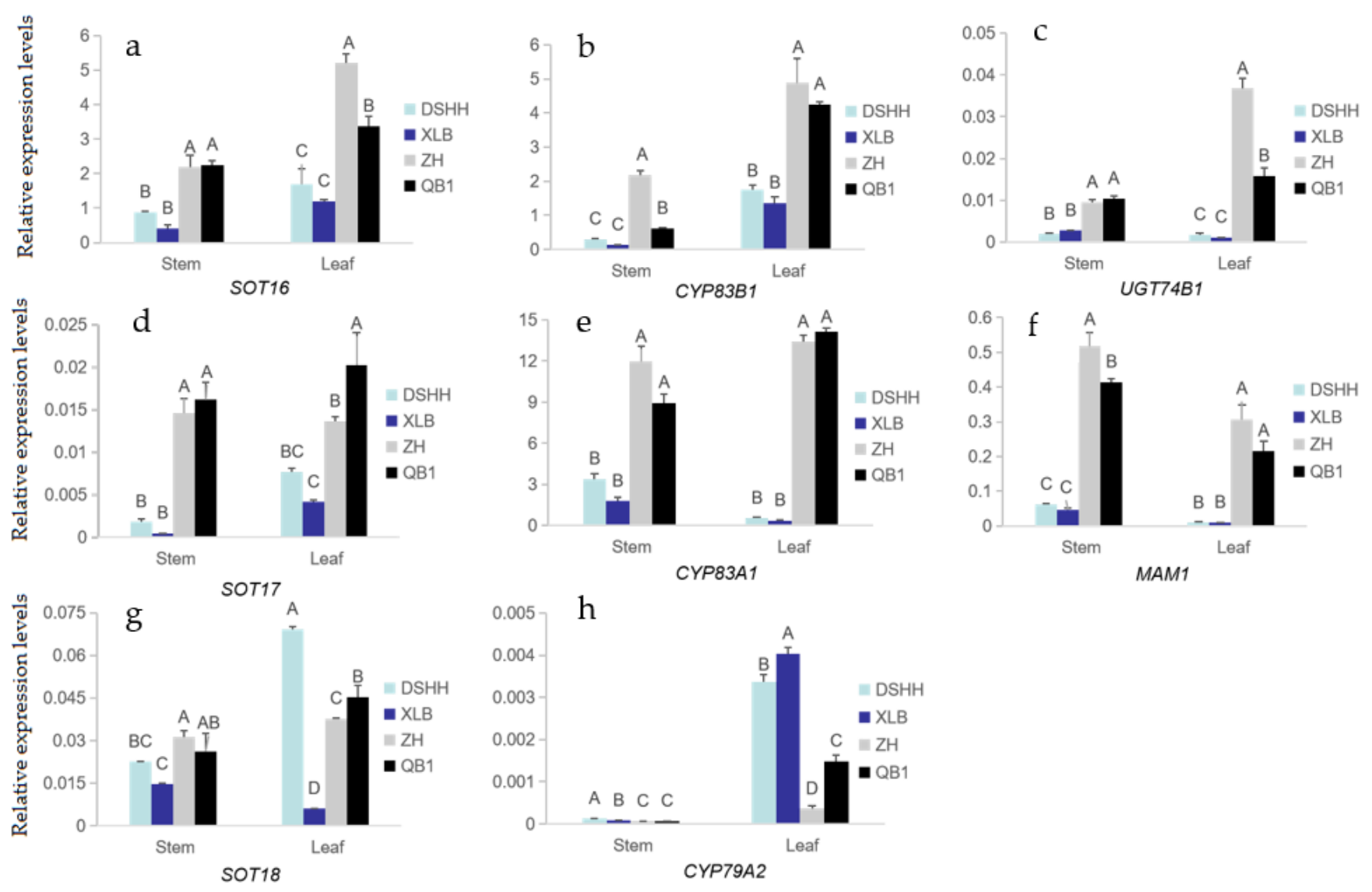

Figure 4. Expression analysis of biosynthetic genes in Chinese kale varieties with different glucosinolate content. (a-h) The relative expression levels of 8 genes determined by qRT-PCR. QB1 and ZH Chinese kale varieties with higher glucosinolate content; XLB and DSHH Chinese kale varieties with lower glucosinolate content. Different capital letters indicate extremely significant differences $(p<0.01)$.

There were significant differences in the expression of each gene in different parts of Chinese kale (Figure $4 \mathrm{~d}-\mathrm{g}$ ). The expression level of $M A M 1$ in the stems is greater than that of leaves in the varieties with high glucosinolate content, but the expression level of CYP83A1 and SOT18 in leaves was greater, and the expression level of SOT17 in the leaves of the QB1 variety is significantly greater than that in the stems. The expression levels of MAM1 and CYP83A1 were higher in stems than in leaves in the low glucosinolate varieties, except the expression levels of SOT17 were more significant in leaves.

Compared with DSHH and XLB varieties with low glucosinolate content, the expression levels of indole glucosinolate biosynthesis genes CYP83B1, UTG74B1 and SOT16 were higher in the stems and leaves of Chinese kale varieties with high glucosinolate content varieties QB1 and ZH. On the contrary, the expression level of CYP79A2 in the leaves was significantly higher than in the stems (Figure 4a,b,h). The expression levels of CYP79A2, CYP83B1, UTG74B1 and SOT16 genes were higher in leaves than in stems in the same varieties (Figure $4 \mathrm{a}-\mathrm{c}, \mathrm{h})$.

In the high glucosinolate varieties, the expression level of CYP83B1 in the stems of the $\mathrm{ZH}$ variety was significantly higher than that of QB1, but there was no significant difference in the leaves (Figure 4b). The expressions of UTG74B1 and SOT16 were not significantly different in the stems, while the expressions were significantly higher in the leaves of $\mathrm{ZH}$ than QB1 (Figure 4a,c). The expression of CYP79A2 in QB1 was also higher than in ZH (Figure 4h). A comparison of two low glucosinolate varieties DSHH and XLB indicates that the expression levels of SOT16, CYP83B1 and UTG74B1 had no significant differences in the stems and leaves, and the expression of CYP79A2 had no significant difference in the stems, but was significantly higher in the leaves of XLB than DSHH (Figure $4 \mathrm{a}-\mathrm{c}, \mathrm{h}$ ). 


\section{Discussion}

Chinese kale is a specialty vegetable of the cruciferous family. It is closely related to common vegetables such as cabbage, mustard and the model plant Arabidopsis thaliana. Chinese kale, Brussels sprout, broccoli, red cabbage and cauliflower all belong to the vegetables of Brassica oleraca, but the glucosinolate content and main component of different varieties and organs are different in Brassica oleracea. The content of glucosinolates in Brussels sprout and broccoli is higher than that in cauliflower and red cabbage. PRO, SIN and GIB are the main components of A-GLSs in Brussels sprout [43]. The representative glucosinolates in Brassica napus, Brassica juncea and Brassica rape are PRO, SIN and GNA, respectively [44]. Although the research indicated that the same glucosinolate component existed in Chinese kale varieties and parts and showed that aliphatic glucosinolate accounted for more than $70 \%$ of the total glucosinolates in all Chinese kale varieties, GNA, GRA and SIN were also main glucosinolate in most Chinese kale varieties. However, there are still great differences in the types, main components and contents of glucosinolates detected by different varieties and detection parts of Chinese kale (Table 6). In this study, eight kinds of glucosinolates were detected from the stems and leaves of sixteen Chinese kale varieties from Japan and China, including four kinds of A-GLSs-GRA, SIN, GNA and GER, and four kinds of I-GLSs-4-HGBS, GBS, 4-MGBS and NGBS, but no aromatic glucosinolates were detected. These results were slightly different from previous studies that recorded 7, 9-11 and 13 kinds of components (Table 6). This may be related to the genotype of the variety studied, the planting location, environmental conditions and the method of determination.

Like other Brassica oleracea, A-GLSs accounted for a large proportion of the T-GLSs in Chinese kale, while the content of I-GLSs was low and the components were basically the same. However, GNA and GRA were the main glucosinolate components in Chinese kale, and the contents of SIN and GER were relatively low [45-47]. In our results, the proportion of aliphatic glucosinolates in edible stems and leaves of Chinese kale varieties from China and Japan was higher than that of other groups, reaching more than $80.69 \%$. Although the content and component of glucosinolates were different, they all showed high GRA and GNA contents, and the GRA content of Chinese kale stems and leaves was higher than that of Japanese varieties, while the GNA content of Japanese varieties was relatively higher. Although the content of SIN in the Chinese kale varieties is lower than that of GRA and GNA, the total content of stems and leaves in most varieties exceeds $30 \mu \mathrm{mol} / 100 \mathrm{~g}$ DW. In addition, PRO was not detected in this study, which is different from previous results. Because the GNA hydrolysate 3-butenyl ITC can induce the death of prostate cancer cells through apoptosis, and GRA and its derived isothiocyanate sulforaphane have anti-inflammatory, anticancer and neuroprotective effects [48-52], the Chinese kale varieties with high GRA and GNA content, such as ZH and QB1 involved in this study, have important nutritional and health functions. Obtaining varieties with high content of GRA and GNA is also the goal of breeding Chinese kale in the future.

A total of 105 genes are associated with the contents and compositions of glucosinolates in Brassica oleracea L. genome, including MAM CYP79, CYP83, ST, AOP, IGMT and other biosynthetic pathway genes, MYB28, MYB29, MYB51 and other transcription factors and 22 catabolic genes [53], but not all genes were expressed in different subspecies of Brassica oleracea [54]. The higher expression of ST5, CYP81F1 and CYP84F1 in subspecies of cabbage, broccoli, and kale in MeJA treatment resulted in the accumulation of higher levels of GBS, while the increase in CYP81F4 gene expression resulted in the production of higher NGBS content. The higher levels of expression of ST5, AOP and GLS-OH genes give cabbage a higher aliphatic glucosinolate content than broccoli and kale [55]. All these results indicate that gene expression of different subspecies and different parts of $B$. oleracea affect the glucosinolate biosynthesis. 
Table 6. The types, main components and content ranges of glucosinolates determined by different methods.

\begin{tabular}{|c|c|c|c|c|c|}
\hline $\begin{array}{c}\text { Resources of Varieties of } \\
\text { Chinese Kale and } \\
\text { Measuring Site }\end{array}$ & Types of GLSs & $\begin{array}{l}\text { Main Components of } \\
\text { GLSs A-GLSs }\end{array}$ & $\begin{array}{l}\text { The Average Content or } \\
\text { Range of T-GLSs (the } \\
\text { Proportion of A-GLSs) }\end{array}$ & Determination Method & References \\
\hline $\begin{array}{l}16 \text { Chinese kale Varieties, } \\
\text { bolting stems, } \\
\text { edible leaves }\end{array}$ & $\begin{array}{c}\text { A-: GRA, SIN, GNA, GER } \\
\text { I-: GBS, 4-MGBS, NGBS, } \\
\text { 4-HGBS }\end{array}$ & GNA, GRA, GBS & $\begin{array}{c}1005.4 \mu \mathrm{mol} / 100 \mathrm{~g} \mathrm{DW} \\
(80.69-96.28 \%)\end{array}$ & LC-MS & This study \\
\hline $\begin{array}{l}22 \text { Chinese kale } \\
\text { varieties, sprout }\end{array}$ & $\begin{array}{c}\text { A-: GNA, SIN, GIB, PRO, } \\
\text { GRA, GER, GAL, GNL } \\
\text { I-: GBS, 4-MGBS, NGBS, } \\
\text { 4-HGBS } \\
\text { R-: GST }\end{array}$ & GNA, PRO, GIB, GBS & $\begin{array}{c}5.51-104.57 \mu \mathrm{mol} \cdot \mathrm{g}^{-1} \mathrm{DW} \\
(85-94 \%)\end{array}$ & HPLC+GC-MS & {$[7]$} \\
\hline $\begin{array}{l}6 \text { Chinese kale cultivars, } \\
\text { mixed sample of } \\
\text { stems leaves }\end{array}$ & $\begin{array}{c}\text { A-: GNA, SIN, GIB, PRO, } \\
\text { GRA, GER, GAL, GNL } \\
\text { I-:GBS, 4-MGBS, NGBS, } \\
\text { 4-HGBS } \\
\text { AR-:GST }\end{array}$ & $\begin{array}{c}\text { GNA, GER, GST, SIN, } \\
\text { GBS }\end{array}$ & $18.93 \mu \mathrm{mol} \cdot \mathrm{g}^{-1} \mathrm{DW}(68.1 \%)$ & HPLC & [56] \\
\hline $\begin{array}{c}7 \text { Chinese kale cultivars, } \\
\text { edible part }\end{array}$ & $\begin{array}{c}\text { A-: GNA, GRA, SIN, PRO, } \\
\text { GER, 2-MBG, 3-MPG } \\
\text { I-:GBS, 4-MGBS, NGBS, } \\
\text { 4-HGBS } \\
\text { R-:GST, GBR }\end{array}$ & GNA, GRA, SIN, GBS & - & $\begin{array}{l}\text { UHPLC-Quadrupole- } \\
\text { Orbitrap } \\
\text { MS/MS }\end{array}$ & [47] \\
\hline $\begin{array}{l}27 \text { Chinese kale Varieties, } \\
\text { sprout, rosette leaf, bolting } \\
\text { stem }\end{array}$ & $\begin{array}{c}\text { A-:GNA, SIN, GIB, PRO, } \\
\text { GRA, GER, GAL, GNL } \\
\text { I-:GBS, -MGBS, NGBS, } \\
\text { 4-HGBS } \\
\text { R-:GST }\end{array}$ & GNA, SIN, GIB, GBS & $\begin{array}{c}\text { Sprout: } 116.25 \mu \mathrm{mol} \cdot \mathrm{g}^{-1} \mathrm{DW} \\
(92.5 \%) \\
\text { rosette leaf: } 8.80(74.0 \%) \\
\text { bolting stem: } 11.61(85.6 \%)\end{array}$ & LC-MS & [21] \\
\hline $\begin{array}{l}10 \text { Chinese kale Varieties, } \\
\text { bolting stem }\end{array}$ & $\begin{array}{l}\text { A-:GIB, PRO, GRA, SIN, } \\
\text { GAL, GNA, GER } \\
\text { I-: GBS,4-MGBS, NGBS, } \\
\text { 4-HGBS }\end{array}$ & GNA, GRA, SIN, GBS & $8.38 \mu \mathrm{mol} \cdot \mathrm{g}^{-1} \mathrm{DW}(81.63 \%)$ & HPLC-PAD-ESI/MS & [41] \\
\hline $\begin{array}{l}43 \text { Chinese kale Varieties, } \\
\text { edible parts of leaves and } \\
\text { flower stalks }\end{array}$ & $\begin{array}{c}\text { A-:GNA, PRO, SIN, GRA, } \\
\text { 4-pentenyl GLSs } \\
\text { I-:GBS, 4-MGBS, NGBS, } \\
\text { 4-HGBS }\end{array}$ & $\begin{array}{l}\text { GNA, NGBS, GBS, PRO, } \\
\text { SIN }\end{array}$ & $8.39 \mathrm{mg} \cdot \mathrm{g}^{-1} \mathrm{DW}(67.3 \%)$ & HPLC & [57] \\
\hline $\begin{array}{l}1 \text { v Chinese kale variety, } \\
\text { leaves, bolting stem }\end{array}$ & $\begin{array}{c}\text { A-:GIB, PRO, SIN, GRA, } \\
\text { GAL, GNA } \\
\text { I-:GBS, 4-MGBS, NGBS, } \\
\text { 4-HGBS }\end{array}$ & GNA, SIN, GIB & $\begin{array}{c}1074.2 \mu \mathrm{g} \cdot \mathrm{g}^{-1} \mathrm{DW} \text { in leaves } \\
(72.8 \%) \\
\begin{array}{c}\left(72.1 \% 07.1 \mu \mathrm{g} \cdot \mathrm{g}^{-1} \mathrm{DW} \text { in stems }\right. \\
(82.1 \%)\end{array}\end{array}$ & HPLC & [58] \\
\hline $\begin{array}{l}7 \text { Chinese kale, } \\
\text { bolting stem }\end{array}$ & $\begin{array}{c}\text { A-:PRO, GRA, GNA } \\
\text { I-:GBS, 4-MGBS, NGBS, } \\
\text { 4-HGBS }\end{array}$ & $\begin{array}{l}\text { GNA, GRA, NGBS, } \\
\text { PRO, GBS }\end{array}$ & $\begin{array}{c}412.47 \mu \mathrm{mol} / 100 \mathrm{~g} \mathrm{FW} \\
(72.08 \%)\end{array}$ & HPLC & {$[20]$} \\
\hline
\end{tabular}

GIB: Glucoiberin; PRO: Progoitrin or Glucorapiferin; GRA: Glucoraphanin; SIN: Sinigrin; GAL: Glucoalyssin; GNA: Gluconapin; GER: Glucoerucin; 2-MBG: 2-methylbutylglucosinolate; 3-MPG: 3-methylpentylglucosinolate; GBS: Glucobrassicin or 3-indolylmethyl-GSs; 4-HGBS: 4-Hydroxyglucobrassicin or 4-hydroxy-3-indolylmethyl- GSs; NGBS: Neoglucobrassicin or 1-methoxy-3-indolylmethyl- GSs; 4MGBS: 4-Methoxyglucobrassicin or 4-methoxy-3- indolylmethyl-GSs; GNL: Gluconapoleiferin; GST: Gluconasturtiin; GBR: Glucoaubrietin.

BCAT4, MAM1 and CYP79F1 are upstream genes of glucosinolate synthesis in Chinese kale, which is also one of the subspecies of B. oleracea. They are highly expressed in Chinese kale genotypes with high GRA content, which may be related to the biosynthesis of aliphatic glucosinolate GRA [37]. The decreased expression levels of CYP83B1, SUR1 and UTG74B1 under $\mathrm{NaCl}$ treatment led to the decreased content of A- and I-GLSs, while the increased expression levels of CYP83B1, SUR1 and UTG74B1 under MeJA treatment led to the increased content of glucosinolates [59]. Further research found that the significantly down-regulated expression levels of MAM1/2, IPMDH1, CYP79F1, CYP83A1, SUR1, UGT74B1, UGT74C1, GSTU20, GSTF9, SOT18, CYP81F3, CYP81F4 and other genes involved in glucosinolates biosynthesis result in the decrease in the contents of A-GLSs, I-GLSs, T-GLSs, GNA, GRA, SIN, 4-MGBS and NGBS in Chinese kale under the treatment of far-red light [34]. In the transgenic Chinese kale overexpressing BoaUGT74B1, the contents of indole and aliphatic GLSs were 1.30-7.11 and 2.13-4.44 times higher than those in the wild type, respectively, and the highest 4-MGBS content in the transgenic "Sijicutiao" was 12.14 times higher than in the control. The highest GBS in "Fuzhouhuanghua" overexpressed plants was 22.76 times that of the control [60]. In our experiments, genes MAM1, CYP83A1, SOT17 and SOT18 involved in the biosynthesis of A-GLSs and CYP83B1, UTG74B1 and SOT16 involved in the synthesis of I-GLSs were significantly more expressed 
in stems and leaves of QB1 and ZH varieties with high glucosinolate content, and in stems and leaves of varieties with high GNA content. The expression levels of MAM1 and CYP83A1 in the stems and leaves of the Chinese kale variety ZH were significantly higher than those of QB1 varieties, which was consistent with the level of GRA content in the stems and leaves. The above results show that the content and components of glucosinolates in Chinese kale are affected by the expression of related genes, as in other subspecies of B. oleracea.

At the same time, we found that there was a certain relationship between the flow of glucosinolate components in the leaves and stems of Chinese kale, and that it was also related to the expression of genes. The expression levels of SOT17 and SOT18 in the A-GLSs synthesis pathway were significantly higher in QB1 than ZH varieties, and the GNA content was correspondingly higher in QB1 varieties, while the content of GRA was higher in $\mathrm{ZH}$ varieties and the MAM1 expression was higher in $\mathrm{ZH}$ varieties. The expression level of UGT74B1 in leaves of Chinese kale varieties with high GBS and 4-HGBS content was significantly higher than that of low-content varieties, while the content of GBS and 4-HGBS in stems was higher in low-content varieties. The expression levels of SOT16 and CYP83B1 genes were similar to the contents of GBS and 4-HGBS in Chinese kale leaves, but opposite to the contents of GBS and 4-HGBS in Chinese kale stems. CYP79A2 regulates the synthesis of aromatic glucosinolate, which is mainly expressed in Chinese kale leaves, but the expression level is very low. No targeted aromatic glucosinolate was detected in corresponding stems and leaves, which may be related to the competition of A-, I- and R-GLSs metabolic flow. Therefore, the influence of these genes on the composition and content of Chinese kale glucosinolate remains to be further verified.

Author Contributions: L.T.: investigation, data curation, formal analysis, software and writingoriginal draft. S.C.: conceptualization, investigation, methodology, formal analysis, resources, funding acquisition and writing-original draft. H.L., C.Z., J.Z.: formal analysis, validation and writing-review and editing. P.L., Z.W., L.Y., Y.Z.: supervision, validation and writing-review and editing. All authors have read and agreed to the published version of the manuscript.

Funding: This research was funded by Hainan Provincial Key Research and Development Program (ZDYF2018094).

Institutional Review Board Statement: The study was conducted according to the guidelines of the Declaration of Helsinki, and approved by the Institutional Review Board (or Ethics Committee) of NAME.

Informed Consent Statement: Informed consent was obtained from all subjects involved in the study.

Acknowledgments: The authors thank Deqing Zhao of Analysis and Testing Center in Chinese Academy of Tropical Agricultural Sciences for his excellent technical assistance.

Conflicts of Interest: The authors declare no conflict of interest.

\section{References}

1. Becerra-Moreno, A.; Alanís-Garza, P.A.; Mora-Nieves, J.L.; Mora-Mora, J.P.; Jacobo-Velázquez, D.A. Kale: An excellent source of vitamin C, pro-vitamin A, lutein and glucosinolates. CyTA J. Food 2014, 12, 298-303. [CrossRef]

2. Abbaoui, B.; Lucas, C.R.; Riedl, K.M.; Clinton, S.K.; Mortazavi, A. Cruciferous vegetables, isothiocyanates, and bladder cancer prevention. Mol. Nutr. Food Res. 2018, 62, 1-14. [CrossRef]

3. Feskanich, D.; Ziegler, R.G.; Michaud, D.S.; Giovannucci, E.L.; Speizer, F.E.; Willett, W.C.; Colditz, G.A. Prospective study of fruit and vegetable consumption and risk of lung cancer among men and women. J. Natl. Cancer Inst. 2000, 92, 1812-1823. [CrossRef]

4. Joseph, M.A.; Moysich, K.B.; Freudenheim, J.L.; Shields, P.G.; Bowman, E.D.; Zhang, Y.; Marshall, J.R.; Ambrosone, C.B. Cruciferous vegetables, genetic polymorphisms in glutathione S-transferases M1 and T1, and prostate cancer risk. Nutr. Cancer 2004, 50, 206-213. [CrossRef] [PubMed]

5. Ménard, R.; Larue, J.P.; Silué, D.; Thouvenot, D. Glucosinolates in cauliflower as biochemical markers for resistance against downy mildew. Phytochemistry 1999, 52, 29-35. [CrossRef]

6. Grubb, C.D.; Abel, S. Glucosinolate metabolism and its control. Trends Plant Sci. 2006, 11, 89-100. [CrossRef]

7. Zeng, W.; Tao, H.; Li, Y.; Wang, J.; Xia, C.; Li, S.; Wang, M.; Wang, Q.; Miao, H. The flavor of Chinese kale sprouts is affected by genotypic variation of glucosinolates and their breakdown products. Food Chem. 2021, 359, 129824. [CrossRef] 
8. Sikorska-Zimny, K.; Beneduce, L. The glucosinolates and their bioactive derivatives in Brassica: A review on classification, biosynthesis and content in plant tissues, fate during and after processing, effect on the human organism and interaction with the gut microbiota. Crit. Rev. Food Sci. Nutr. 2021, 61, 2544-2571. [CrossRef] [PubMed]

9. Lafarga, T.; Bobo, G.; Vinas, I.; Collazo, C.; Aguilo-Aguayo, I. Effects of thermal and non-thermal processing of cruciferous vegetables on glucosinolates and its derived forms. J. Food Sci. Technol. 2018, 55, 1973-1981. [CrossRef] [PubMed]

10. Hill, C.B.; Williams, P.H.; Carlson, D.G.; Tookey, H.L. Variation in glucosinolates in oriental brassica' vegetables. J. Am. Soc. Hortic. Sci. 1987, 112, 309-313.

11. Nugrahedi, P.Y.; Oliviero, T.; Heising, J.K.; Dekker, M.; Verkerk, R. Stir-frying of Chinese cabbage and pakchoi retains healthpromoting glucosinolates. Plant Foods Hum. Nutr. 2017, 72, 439-444. [CrossRef] [PubMed]

12. He, H.; Ping, L.; Bonnema, G.; Dekker, M.; Verkerk, R. Genetic variation in glucosinote content within Brassica rapa vegetables. Acta Hortic. 2012, 944, 129-140.

13. Frazie, M.D.; Kim, M.J.; Ku, K.M. Health-promoting phytochemicals from 11 mustard cultivars at baby leaf and mature stages. Molecules 2017, 22, 1749. [CrossRef] [PubMed]

14. Velasco, L.; Becker, H.C. Variability for seed glucosinolates in a germplasm collection of the genus Brassica. Genet. Resour. Crop Evol. 2000, 47, 231-238. [CrossRef]

15. Velasco, L.; Becker, H.C. Analysis of total glucosinolate content and individual glucosinolates in Brassica spp. by near-infrared reflectance spectroscopy. Plant Breed. 1998, 117, 97-102. [CrossRef]

16. Hanschen, F.S.; Schreiner, M. Isothiocyanates, nitriles, and epithionitriles from glucosinolates are affected by genotype and developmental stage in Brassica oleracea varieties. Front. Plant Sci. 2017, 8, 1095. [CrossRef]

17. Ku, K.M.; Jeffery, E.H.; Juvik, J.A. Optimization of methyl jasmonate application to broccoli florets to enhance health-promoting phytochemical content. J. Sci. Food Agri. 2014, 94, 2090-2096. [CrossRef]

18. Carlson, D.G.; Daxenbichler, M.E.; Van Etten, C.H.; Kwolek, W.F.; Williams, P.H. Glucosinolates in crucifer vegetables: Broccoli, Brussels sprouts, cauliflower, collards, kale, mustard greens and kohlrabi. J. Am. Soc. Hortic. Sci. 1987, 112, $173-178$.

19. Oerlemans, K.; Barrett, D.M.; Suades, C.B.; Verkerk, R.; Dekker, M. Thermal degradation of glucosinolates in red cabbage. Food Chem. 2006, 95, 19-29. [CrossRef]

20. He, H.; Song, S.; Wang, W.; Xu, X. HPLC identification of intact glucosinolates in Chinese kale. Mod. Instrum. $2002,5,10-12$.

21. Sun, B.; Liu, N.; Zhao, Y.; Yan, H.; Wang, Q. Variation of glucosinolates in three edible parts of Chinese kale (Brassica alboglabra Bailey) varieties. Food Chem. 2011, 124, 941-947. [CrossRef]

22. Klopsch, R.; Witzel, K.; Artemyeva, A.; Rupperl, S.; Hanschen, F.S. Genotypic profiling of glucosinlats and their breakdown products in leaves of Brassica rapa. J. Agric. Food Chem. 2018, 66, 5481-5490. [CrossRef] [PubMed]

23. Sønderby, I.E.; Geu-Flores, F.; Halkier, B.A. Biosynthesis of glucosinolates-gene discovery and beyond. Trends Plant Sci. 2010, 15, 283-290. [CrossRef] [PubMed]

24. Yuji, S.; Ayuko, A.; Mutsumi, N.; Tomoko, N.; Akane, S.; Kazuki, S.; Masamo, Y.H. Omics-based approaches to methionine side chain elongation in Arabidopsis: Characterization of the genes encoding methylthioalkylmalate isomerase and methylthioalkyl malate dehydrogenase. Plant Cell Physiol. 2009, 50, 1181-1190.

25. Yuji, S.; Kiminori, T.; Ayuko, K.; Akane, S.; Mutsumi, N.; Kazuki, S.; Masami, Y.H. Arabidopsis bile acid: Sodium symporter family protein 5 is involved in methionine-derived glucosinolate biosynthesis. Plant Cell Physiol. 2009, 50, $1579-1586$.

26. Hull, A.K.; Vij, R.; Celenza, J.L. Arabidopsis cytochrome P450s that catalyze the first step of tryptophan-dependent indole- 3-acetic acid biosynthesis. Proc. Natl. Acad. Sci. USA 2000, 97, 2379-2384. [CrossRef]

27. Mikkelsen, M.D.; Hansen, C.H.; Wittstock, U.; Halkier, B.A. Cytochrome P450 CYP79B2 from Arabidopsis catalyzes the conversion of tryptophan to indole-3-acetaldoxime, a precursor of indole glucosinolates and indole-3-acetic acid. J. Biol. Chem. 2000, 275, 33712-33717. [CrossRef]

28. Bak, S.; Feyereisen, R. The involvement of two P450 enzymes, CYP83B1 and CYP83A1, in auxin homeostasis and glucosinolate biosynthesis. Plant Physiol. 2001, 127, 108-118. [CrossRef]

29. Mikkelsen, M.D.; Naur, P.; Ahalkier, B. Arabidopsis mutants in the C-S lyase of glucosinolate biosynthesis establish a critical role for indole-3-acetaldoxime in auxin homeostasis. Plant J. 2004, 37, 770-777. [CrossRef]

30. Grubb, C.D.; Zipp, B.J.; Kopycki, J.; Schubert, M.; Quint, M.; Lim, E.-K.; Bowles, D.J.; Pedras, M.S.C.; Abel, S. Comparative analysis of Arabidopsis UGT74 glucosyltransferases reveals a special role of UGT74C1 in glucosinolate biosynthesis. Plant J. 2014, 79, 92-105. [CrossRef]

31. Grubb, C.D.; Zipp, B.J.; Ludwig-Muller, J.; Masuno, M.N.; Molinski, T.F.; Abel, S. Arabidopsis glucosyltransferase UGT74B1 functions in glucosinolate biosynthesis and auxin homeostasis. Plant J. 2005, 40, 893-908. [CrossRef]

32. Piotrowski, M.; Schemenewitz, A.; Lopukhina, A.; Muller, A.; Janowltz, T.; Weiler, E.W.; Oecking, C. Desulfoglucosinolate sulfotransferases from Arabidopsis thaliana catalyze the final step in the biosynthesis of the glucosinolate core structure. J. Biol. Chem. 2004, 279, 50717-50725. [CrossRef]

33. Zhang, Y. Function Analyses of Several Genes Involved in Biosynthesis and Regulation of Glucosinolate in Brassica Napus and Arabidopsis Thaliana. Ph.D. Thesis, Huazhong Agricultural University, Wuhan, China, 2015.

34. Li, Y.; Gao, M.; He, R.; Zhang, Y.; Song, S.; Su, W.; Liu, H. Far-red light suppresses glucosinolate profiles of Chinese kale through inhibiting genes related to glucosinolate biosynthesis. Environ. Exp. Bot. 2021, 188, 104507. [CrossRef] 
35. Naur, P.; Petersen, B.L.; Mikkelsen, M.D.; Bak, S.; Rasmussen, H.; Olsen, C.E.; Halkier, B.A. CYP83A1 and CYP83B1, two nonredundant cytochrome P450 enzymes metabolizing oximes in the biosynthesis of glucosinolates in Arabidopsis. Plant Physiol. 2003, 133, 63-72. [CrossRef] [PubMed]

36. Jiang, D. Cloning and Functional Studies of the BocGTR1s Related to the Glucosinolate Transporter of Chinese Kale. Master's Thesis, South China Agricultural University, Guangzhou, China, 2018.

37. Yin, L. Molecular Cloning, Expression Pattern and Characterization on Glucoraphanin Biosynthetic Related Genes in Chinese Kale (Brassica oleracea var. alboglabra Bailey). Ph.D. Thesis, South China Agricultural University, Guangzhou, China, 2016.

38. Kim, M.; Chiu, Y.C.; Kim, N.; Park, H.; Lee, C.; Juvik, J.; Ku, K.M. Cultivar-specific changes in primary and secondary metabolites in Pak choi by methyl jasmonate. Int. J. Mol. Sci. 2017, 18, 1-17.

39. Kim, S.; Chiami, K.; Ishii, G. Effect of ammonium: Nitrate nutrient ratio on nitrate and glucosinolate contents of hydroponicallygrown rocket salad (Eruca sativa Mill.). Soil Sci. Plant Nutr. 2006, 52, 387-393. [CrossRef]

40. Krumbein, A.B.; Schonhof, I.; Schreiner, M. Composition and contents of phytochemicals (glucosinolates, carotenoids and chlorophylls) and ascorbic acid in selected Brassica species (B. juncea, B. campestris, B. rapa). J. Appl. Bot. Food Qual. 2005, 79, 168-174.

41. La, G.; Liu, G.; Fang, P. Glucosinolates in ten cultivars of Chinese kale (Brassica alboglabra LH Bailey) seperation and identification by HPLC-PAD-ESI/MS[C]/ /2011. In Proceedings of the International Conference on New Technology of Agricultural Engineering, Zibo, China, 27-29 May 2011; IEEE: Piscataway, NJ, USA, 2011; pp. 979-983.

42. Yuan, W.; Yuan, S.; Chen, L.; Liu, Z.; Wang, K.; Qiu, Z. Identification and analysis of components of glucosinolates in succulent roots and leaves of fruity radish (Raphanus sativas L.). Asian Agric. Res. 2018, 10, 84-88.

43. Zabaras, D.; Roohani, M.; Krishnamurthy, R.; Cochet, M.; Delahunty, C.M. Characterisation of taste-active extracts from raw Brassica oleracea vegetables. Food Funct. 2013, 4, 592-601. [CrossRef] [PubMed]

44. Qin, H.; Zhang, W.; Wang, M.; Xiong, S.; Hu, D.; Sun, X.; Hu, L.; Meng, J.; Zou, J. Characterizing glucosinolates of four Brassica species and interspecific transferring of specific glucosinolates. J. Plant Genet. Resour. 2020, 21, 94-104.

45. Qian, H.; Sun, B.; Miao, H.; Cai, C.; Xu, C.; Wang, Q. Variation of glucosinolates and quinone reductase activity among different varieties of Chinese kale and improvement of glucoraphanin by metabolic engineering. Food Chem. 2015, 168, 321-326. [CrossRef]

46. Sun, B.; Yan, H.; Zhang, F.; Wang, Q. Effects of plant hormones on main health-promoting compounds and antioxidant capacity of Chinese kale. Food Res. Int. 2012, 48, 359-366. [CrossRef]

47. Wang, Y.; Hu, L.; Liu, G.; Zhang, D.; He, H. Evaluation of the nutritional quality of Chinese kale (Brassica alboglabra Bailey) using UHPLC-Quadrupole-Orbitrap MS/MS-Based metabolomics. Molecules 2017, 22, 1-17.

48. Arora, R.; Kumar, R.; Mahajan, J.; Vig, A.P.; Singh, B.; Arora, S. 3-Butenyl isothiocyanate: A hydrolytic product of glucosinolate as a potential cytotoxic agent against human cancer cell lines. J. Food Sci. Technol. 2016, 53, 3437-3445. [CrossRef]

49. Vallejo, F.; Tomás-Barberán, F.; García-Viguera, C. Health-promoting compounds in broccoli as influenced by refrigerated transport and retail sale period. J. Agric. Food Chem. 2003, 51, 3029-3034. [CrossRef] [PubMed]

50. Fahey, J.W.; Zhang, Y.; Talalay, P. Broccoli sprouts: An exceptionally rich source of inducers of enzymes that protect against chemical carcinogens. Proc. Natl. Acad. Sci. USA 1997, 94, 10367-10372. [CrossRef]

51. Guerrero-Beltrán, C.E.; Calderón-Oliver, M.; Pedraza-Chaverri, J.; Chirino, Y.I. Protective effect of sulforaphane against oxidative stress: Recent advances. Exp. Toxicol. Pathol. 2012, 64, 503-508. [CrossRef] [PubMed]

52. Pu, D.; Zhao, Y.; Chen, J.; Sun, Y.; Lv, A.; Zhu, S.; Luo, C.; Zhao, K.; Xiao, Q. Protective effects of sulforaphane on cognitive impairments and AD-like lesions in diabetic mice are associated with the upregulation of Nrf2 transcription activity. Neuroscience 2018, 381, 35-45. [CrossRef]

53. Liu, S.; Liu, Y.; Yang, X.; Tong, C.; Edwards, D.; Parkin, I.A.P.; Zhao, M.; Ma, J.; Yu, J.; Huang, S.; et al. The Brassica oleracea genome reveals the asymmetrical evolution of polyploid genomes. Nat. Commun. 2014, 5, 3930. [CrossRef]

54. Yi, G.E.; Arif, R.; Yang, K.; Jong-in, P.; Kang, J.K.; Yang, T.J.; Ill-Sup, N. Identification and expression analysis of glucosinolate biosynthetic genes and estimation of glucosinolate contents in edible organs of Brassica oleracea subspecies. Molecules 2015, 20, 13089-13111. [CrossRef]

55. Yi, G.E.; Arif, R.; Yang, K.; Jong-in, P.; Byung, H.; Ill-Sup, N. Exogenous methyl jasmonate and salicylic acid induce subspeciesspecific patterns of glucosinolate accumulation and gene expression in Brassica oleracea L. Molecules 2016, 21, 1417. [CrossRef] [PubMed]

56. Chang, J.; Wang, M.; Jian, Y.; Zhang, F.; Sun, B. Health-promoting phytochemicals and antioxidant capacity in different organs from six varieties of Chinese kale. Sci. Rep. 2019, 9, 20344. [CrossRef] [PubMed]

57. Si, Y.; Chen, G.; Lei, J.; Cao, B.; Feng, A. Analysis on composition and content of glucosinolates in different genotypes of Chinese kale. China Veg. 2009, 6, 7-13.

58. Chen, X.; Zhu, Z.; Yang, J.; Liu, Y.H. Composition and content of glucosinolates in leaves and bolting stem s of Chinese kale quantified by HPLC. Acta Hortic. Sin. 2006, 4, 741-744.

59. Wu, Q.; Wang, J.; Mao, S.; Xu, H.; Wu, Q.; Liang, M.; Yuan, Y.; Liu, M.; Huang, K. Comparative transcriptome analyses of genes involving in sulforaphane metabolism at different treatment in Chinese kale using full-length transcriptome sequencing. BMC Genom. 2019, 20, 377. [CrossRef]

60. Zheng, H.; Zhang, C.; Wang, Y.; Zhou, W.; Sun, B. Overexpression of the glucosyltransferase gene BoaUGT74B1 enhances the accumulation of indole glucosinolates in Chinese kale. Sci. Hortic. 2021, 288, 110302. [CrossRef] 